\title{
Structural and chemical heterogeneity of layer silicates and clay minerals
}

\author{
V. A. DRITS* \\ Geological Institute, Russian Academy of Sciences, 7 Pyzhevsky Street, 109017 Moscow, Russia
}

(Received 10 April 2003; revised 31 August 2003)

\begin{abstract}
Different forms of structural and chemical heterogeneity are considered including mixed-layer minerals, disordered layer structures containing rotational and translational stacking faults, interstratification of trans-vacant $(t v)$ and cis-vacant $(c v)$ layers in true micas, illites and illitesmectite (I-S), short-range order in isomorphous cation distribution etc.

Because determination of various structural and chemical imperfections requires elaboration of new diffraction and spectroscopic methodologies, special attention is paid to recent achievements in the development of new methodological approaches such as a multispecimen simulation of experimental X-ray diffraction (XRD) patterns from mixed-layer minerals, with account taken of layer-thickness fluctuations of the second type and possible difference between structures of outer and core layers; experimental determination of thickness distribution of illite crystals by HRTEM and the modified Bertaut-Warren-Averbach technique; XRD and thermal methods for determination of $c v$ and $t v$ layers in true micas, illites and I-S; generalization of Méring's rules to account for the behaviour of non-basal reflections for any defective structure in which two translations are irregularly interstratified; various $a b$ initio calculations devoted to modelling infrared $\mathrm{OH}$ vibrations, octahedral cation distribution in dioctahedral 2:1 layer silicates, etc. It is shown that these recentlydeveloped methodologies have revealed new diversity in the structural and chemical heterogeneity of phyllosilicates and clay minerals, provided new insight into the structural mechanisms of their transformation in different geological environments, and discovered new natural processes.
\end{abstract}

KEYWORDS: heterogeneity, layer silicates, clay minerals, mixed layers, illite, illite-smectite, mica.

The study of structural and chemical heterogeneity of minerals is one of the main domains in modern structural mineralogy. Determination of various imperfections that violate the uniform and periodic structure of crystals has great scientific and practical significance. As a matter of fact, the types of defects, their content and the distribution strongly modify physicochemical properties of crystals, reflect the specific physicochemical conditions of mineral formations, allow reconstruction of structural mechanisms of phase transformations, etc.

The origin of structural and chemical heterogeneity of layer minerals is predetermined by the very nature of their structure. On the one hand, different layers have similar or identical two-

* E-mail: dritsva@geo.tv-sign.ru DOI: $10.1180 / 0009855033840106$ dimensional periodicity and similar structure of their outer basal surfaces. For these reasons, structurally and chemically different layers may coexist within one and the same crystal, leading to the formation of mixed-layer structures. On the other hand, layers in layer pairs may stack in several, energetically similar ways. Therefore, layer minerals often contain stacking faults due to irregular layer rotations, displacements, microtwinning, etc. Finally, layer minerals are usually characterized by complex chemical composition and a wide spectrum of isomorphous cation distributions. In addition, crystallization of minerals in a fine-dispersed state is also a specific type of imperfection and the study of such minerals should include analysis of structural and chemical heterogeneity of individual crystallites as well as heterogeneity in their size distribution. 
It is natural that determination of various structural and chemical imperfections requires development of new diffraction and spectroscopic methodologies. In particular, a strong impetus for new theoretical and methodological developments was given by the need to interpret diffraction effects observed for defective layer structures (Méring, 1949; Brindley \& Méring, 1951; James, 1965; Guinier, 1964; Kakinoki \& Komura, 1952, 1954; Drits \& Tchoubar, 1990; Drits \& Sakharov, 1976; Plançon \& Tchoubar, 1977; Drits et al., 1984, 1994; Drits \& McCarty, 1996; Plançon, 1981, 2001, 2002, 2003; Reynolds, 1980, 1985, 1993). One remarkable feature of these effects is their ability to extract average structural characteristics of crystals deprived of 3D periodicity. On the other hand, diffraction effects from disordered structures do not obey Bragg's law and cannot be interpreted by conventional structural analysis techniques. Therefore reliable determination of structural and chemical heterogeneity of layer minerals depends on the reliable interpretation of experimental data obtained by diffraction methods. A similar situation occurs with determination of local cation environments and short-range order in the distribution of isomorphous cations by spectroscopic methods because interpretation of their spectra is often based on the 'finger print' or other semi-empirical approaches (Drits, 1985).

That is why, in this paper, special attention will be paid to recent methodological approaches (combined with their practical applications) to the study of defective layer structures. The structural and chemical heterogeneity of layer silicates and clay minerals associated with interstratification of different layer types; interstratification of identical layers having different azimuthial orientations and translations; interstratification of layers having identical thickness but different inner structure and interlayer translations; and short-range order in isomorphous cation distribution, will be dealt with here.

\section{MIXED-LAYER STRUCTURES}

\section{Marcovian statistics, structural and chemical heterogeneity, Méring's rules}

To describe the distribution of layer types in irregular mixed-layer structures, Marcovian statistics are usually used. An important parameter in this model is the short-range order factor $R$ defined as the number of preceding layers that influence the occurrence probability for a subsequent layer of a given type. Each $R$ value is related to a set of conditional probability parameters, and one of the main problems is to determine these parameters in order to describe the layer stacking sequence in a mineral under study (Drits \& Tchoubar, 1990).

It follows from the Marcovian statistics that a mixed-layer dispersed mineral is a physical mixture, or assemblage, of statistically weighted crystallites or coherent scattering domains (CSDs). The thickness of a CSD is determined by the number of interstatified layers parallel to each other in the $a b$ plane. The remarkable feature of such an assemblage is that CSDs in the mixed-layer sample have quite different structure and composition (Drits, 1987a,b, 1997). In general, the degree of heterogeneity of the composition of CSDs in mixed-layer samples is a function of the total number of layers in CSDs, the proportion of interstratified A and B layers, and the pattern in the sequence of layer types. For example, let us consider the heterogeneity in proportions of interstratified A and B layers in a mixed-layer sample in which each crystallite contains 10 layers, the average content of $\mathrm{A}$ and $\mathrm{B}$ layers are 60 and $40 \%$ and $R=0$. It can be shown that the portion of crystallites consisting of $6 \mathrm{~A}$ and $4 \mathrm{~B}$ layers, corresponding to the average content of $\mathrm{A}$ and $\mathrm{B}$ layers in the sample, is only $25 \%$. The remaining $75 \%$ of crystals have other compositions. If $R=1$, the homogeneity of the sample increases but the portion of crystallites containing 6A and 4B layers still remains $<50 \%$ (Drits, 1987a). The other source of heterogeneity is that crystallites having the same composition differ from each other in the distribution of layer types. Thus, in terms of the Marcovian model, the heterogeneity of a powder mixed-layer sample results both from the heterogeneity of the CSD compositions (A:B ratio) and from different distribution of layers in crystallites with a fixed A:B ratio. In addition, the heterogeneity of mixed-layer samples depends on the range within which thicknesses of CSDs vary and on the distribution of thicknesses within that range.

It is natural that an XRD pattern of a mixed-layer sample is a statistically weighted sum of XRD patterns, each of which corresponds to individual CSDs having the same composition and distribution of layer types. Positions and profiles of basal reflections recorded in the XRD patterns from twocomponent structures with $R=0$ are determined by Méring's rules (Méring, 1949). 
According to these rules, basal reflections for a random two-component structure are located between the neighbouring $00 l$ reflections corresponding to periodic structures whose layers are interstratified. The width of the reflections increases with the distances between these neighbouring $00 l$ reflections, and their location depends on the proportion of the interstratified layer types. Méring's rules, in combination with two rules added by Drits and Sakharov (1976) and Drits et al. (1994), provide the best insights into the nature of diffraction from mixed-layer structures. In particular, they explain the origin of irrational series of basal reflections in XRD patterns for irregular mixed-layer minerals with $R \geqslant 1$ and predict general regularities in the formation of diffraction effects from such structures. A simple technique based on these rules allows semiquantitative determination of proportions of layer types for two-component mixed-layer structures with any $R$ and any thicknesses of interstratified layers (Drits et al., 1994). Mérings rules are an essential component of computer expert systems developed for a semi-qualitative phase analysis of clays containing periodic and mixed-layer minerals (Drits \& Plançon, 1994; Plançon \& Drits, 1994, 2000).

Nadeau et al. (1984) suggested another interpretation of diffraction effects from mixed-layer structures, considering their XRD patterns to be a result of interparticle diffraction, i.e. diffraction between so-called fundamental particles. For example, in terms of this model, I-S structure can be considered as an aggregate of smectite 2:1 monolayers and illite fundamental particles or illite crystals that consist of two or more 2:1 layers bonded by interlayer $\mathrm{K}$. Although simulation of XRD patterns from natural mixed-layer minerals in terms of this model is a complex task, its general conception is useful in many aspects. In particular, diagenetic evolution of I-S is accompanied not only by increasing illite layer content and structural order in layer sequences but also by increasing mean thickness of illite crystals and by modification of their thickness distribution.

\section{Experimental measurements of thickness distributions of illite crystals in I-S}

Recent investigations of crystal size and size distributions have shown that these characteristics can be used for reconstruction of geological history and for better understanding of crystal growth processes (Eberl et al., 1998a, 2002; Merriman et al., 1990; Środoń, 2002). In particular, Eberl et al. (1998a) developed theoretical approaches, according to which each crystal growth mechanism is accompanied by a specific shape of crystal-size distribution. This means that it is possible to solve the reverse problem, i.e. to use crystal-size distribution to determine the law of crystal growth and so deduce the relative reaction history of mineral formation. One of the critical points in the solution of the problem is to provide careful and accurate crystal-size measurements. These requirements have stimulated the development of new methodologies for the determination of size parameters of clay minerals (Arkai et al., 1996; Guthrie and Veblen, 1989; Środoń et al., 1990, 2000; Środoń, 2002; Elsass et al., 1998; Uhlik et al., 2000; Drits et al., 1997d).

Among XRD methods, the Bertaut-WarrenAverbach (BWA) technique is most universal because it analyses reflection profiles and determines crystal-size distributions. Drits et al. (1998a) modified this technique to apply it to clay minerals and developed the MudMaster computer program (Eberl et al., 1996). It should be emphasized that the BWA method can be applied only to clay minerals having a periodic structure at least along the $c^{*}$ direction. Eberl et al. (1998b) showed that saturation of I-S with polymer polyvinylpyrrolidone (PVP) is accompanied by separation of individual smectite monolayer and illite crystals or fundamental particles in such a way that they scatter $\mathrm{X}$-rays independently from each other. Therefore, the PVP-treated I-S sample is a set of individual particles for which interparticle diffraction observed for the non-treated sample is eliminated. Eberl et al. (1998b) used the BWA method to determine mean thickness and thickness distribution of illite crystals in I-S from diagenetic and hydrothermal bentonites. They showed that the mean thicknesses of illite crystals are similar to those determined by the Ptshadowing TEM technique. In addition, they found that, as a rule, variations of illite crystals in the I-S samples studied follow log-normal distributions characterized by two independent parameters: the mean of the logarithms of coherent scattering domain (CSD) thickness, $\alpha$, and the variance of the logarithms of CSDs, $\beta^{2}$.

Recently, Dudek et al. (2002) compared thickness distribution of illite crystals in I-S using MudMaster and HRTEM. I-S samples from shales 
and bentonites were treated with PVP. It was found that the area-weighted distribution determined by XRD contains a larger fraction of thick (> $40 \AA$ ) and a smaller fraction of thin crystals compared to the number-weighted distribution obtained by HRTEM. Nevertheless, for the fine fraction of illite crystals $(<100 \AA)$, both techniques produce similar thickness distributions. In contrast to bentonitic I-S, for shale I-S, illite crystal-thickness distributions are not lognormal and can be considered as a superposition of several lognormal distributions having different $\alpha$ and $\beta^{2}$ values.

Środon et al. (2000) studied the evolution of illite and smectite fundamental particles during smectite illitization in order to determine the structural mechanism of this reaction. Thickness distributions of these particles from bentonitic and hydrothermally altered pyroclastics were determined by a Ptshadowing TEM technique. The log-normal distribution of the area-weighted illite crystal thickness indicates the operation of a unique mechanism of the illitization process, which was simulated using the mathematical form of the Law of Proportionate Effect. It was found that illite particles grow from $20 \AA$ thick illite nuclei by surface-controlled growth. Initially formed, these $20 \AA$ crystals may grow from material produced by dissolution of smectite monolayers. After nucleation ceases, illite crystals continue to grow and the rate of growth is restricted by how rapidly crystallization proceeds, given a nearly infinite supply of reactants. This period of illitization is characterized by $3 \mathrm{D}$ growth. It was shown that Ostwald ripening, supplycontrolled growth, the coalescence of smectite layers and other crystal-growth mechanisms do not produce a log-normal distribution and the observed evolution of its parameters.

\section{Multispecimen XRD technique}

Quantitative structural analysis of mixed-layer minerals based on a trial-and-error approach requires the maximum possible agreement between the experimental XRD pattern and that calculated for a model corresponding to the actual structure of a mixed-layer sample. However, this is not a trivial task, and in practice, possibilities provided by computer simulation of experimental XRD patterns have seldom been used properly. Conventionally, in most of the publications, interpretation of the experimental XRD patterns is confined to the analysis of positions of basal reflections often ignoring their intensities and profiles. This approach employs peak migration curves which, in the form of plots or tables, represent relationships between basal reflection positions and proportions and mode of interstratification of layer types. Because this approach is restricted to two-component systems in which the thicknesses of interstratified layers are fixed, essential details of the actual structure of mixed-layer minerals may be poorly understood or even overlooked (Drits, 1997).

Therefore more reliable results are achieved when not only $d$ values but also intensities and profiles of basal reflections coincide in the experimental and calculated XRD patterns. Even in this case, however, the actual structure of mixedlayer samples is not always unambiguously determined. The main reason is that several structural models may fit the experimental XRD pattern equally well (Sakharov et al., 1999a; Drits et al., 2002a). To increase the reliability of the results, the multispecimen XRD method was proposed by Drits et al. (1997a) and Sakharov et al. (1999a). It is based on two main requirements. First, a unique statistical model should describe the XRD patterns obtained for several specimens of the same sample subjected to different treatments: saturation by different interlayer cations, glycolation, heating etc. Second, the best possible agreement between the experimental and calculated reflections should be achieved as regards not only their positions but also intensities and profiles. The principle of the multispecimen method is that each different treatment of the same sample is an independent test of validity for the statistical structural model because each treatment changes the thickness and scattering efficiency of the swelling layers, but not the $2: 1$ or $1: 1$ layers and their distribution.

Application of the multispecimen method provides a more reliable interpretation of experimental XRD patterns and greater accuracy in the determination of structural and probability parameters (Drits et al., 1997a, 2002a,b; Sakharov et al., 1999a,b; Lindgreen et al., 2000, 2002). A significant advantage of the method is that it can be applied to mixed-layer structures containing 3, 4 or more interstratified components with different distributions of individual layer types. Another important advantage of this approach is that it provides quantitative phase analysis of samples consisting of periodic and interstratified clay 
minerals (Drits et al., 2002a,b; Lindgreen et al., $2000,2002)$. The main disadvantage is that the approach is time-consuming, and one of the future tasks is to provide automation for the fitting procedure.

Two additional types of structural heterogeneity should be taken into account to describe the actual structure of mixed-layer minerals using the multispecimen method: microstrains and the potential opportunity for outer surface layers to be different from layer types of the core structure.

\section{Layer-thickness fluctuation or microstrains}

These defects result from the presence in layer structures of structural imperfections that disturb parallel layer packings (Warr \& Neito, 1998) such as edge dislocations, lateral layer terminations, bending layers, cracks, deformation, layer thickness fluctuations, etc. As a result, the actual layerstructure translations between adjacent layers may vary around the mean value. These variations may occur along the $c^{*}$ axis, as well as along crystallographic directions in the $a b$ plane, modifying intensities of basal and non-basal reflections, respectively. The translations' variations may be described by a statistical distribution function of the distances between nearest layer neighbours. Depending on the nature of the interactions between the layers and the physical reasons for the translations' variations, disorder of the first and of the second type are distinguished (Guinier, 1964). Disorder of the first type along $c^{*}$ includes layer-thickness fluctuations which follow the same law for any layer pair, i.e. a single law describes both short-range and long-range order in a layer stack. Disorder of the second type follows a distance distribution law, in which there is no correlation between the distances of successive adjacent layers. It means that the distance distribution function between first nearest neighbours is independent of the distance fluctuations between other pairs of layer neighbours. Defects of the first type decrease the intensity of basal reflections with increasing diffusion vector $(s=2 \sin v / \lambda)$ but not their profiles. In contrast, microstrains of the second type decrease intensity and increase broadening of basal reflections with $s$. The mathematical formalism describing intensity distribution for basal and non-basal reflections in periodic and mixed-layer structures containing disorders of the second type has been deduced by
Drits \& Tchoubar (1990). In particular, regarding the law of distribution of the translations it is assumed that it is a normal Gaussian having a specific standard deviation for each given layer type. Our experience shows that the quality of the fit significantly improved when the layer-thickness fluctuation effect in I-S samples was taken into account (Drits et al., 1997a, 2002a; Sakharov et al., 1999a; Lindgreen et al., 2000).

Plançon (2002) described a similar approach, in which the law of distribution of translations between particular layer pairs is given as the number of particular translations occurring with particular probability. His aim was to explain an apparent contradiction between the experimental data obtained for the same smectite and I-S samples by different techniques. In particular, according to the small-angle X-ray scattering technique, I-S particles consist of large numbers of parallel layers, whereas simulation of the I-S diffraction patterns shows very thin CSDs. To illustrate the opportunity of the approach, XRD patterns were calculated for two random I-S models with $W_{\mathrm{I}}=W_{\mathrm{S}}$ $=0.5$. In one model a uniform distribution of CSD thickness between 2 and 13 layers was used and its XRD pattern was calculated using a conventional diffraction technique. In the second model, in each crystallite consisting of 50 layers, an arbitrary distribution of additional distances between each type of layers of $2,4,6$ and $8 \AA$ with respective probability of 0.05 for each of them was used. Comparison of the XRD patterns showed that the second model significantly improves the degree of resolution of the first low-angle basal reflection but led to displacement of position of the second basal reflections with respect to that observed in the XRD pattern of the first model. The problem in the practical application of this approach is that modes of distributions of translations between different layer pairs in a particular layer mineral is not known a priori. It would be interesting to compare experimental XRD patterns of mixed-layer minerals with those calculated using this approach.

\section{Outer surface layers covering core structure of periodic and mixed-layer minerals}

Tsipursky et al. (1992) were the first to demonstrate that layers covering outer surfaces of crystallites and layers of the core structure may be different. In particular, it was shown by highresolution transmission electron microscopy 
(HRTEM) that in illite samples, the outer surface layers of the particles are represented by kaolinite layers.

Recently Ma \& Eggleton (1999), using HRTEM, showed that the surface layers in kaolinite crystallites may also have different structure. In particular, a $10 \AA$ pyrophyllite-like (or low-charge beidellitelike) layer is located on one side of these crystallites as a surface layer. Kaolinite particles of the other type contain one or several $10 \AA$ layers on their both sides. Kogure et al. (2001) also observed a crondstedtite crystal terminated by a chlorite unit layer. Ma \& Eggleton (1999) noted that the $10 \AA$ surface layers were not detected by XRD. However, Sakharov et al. (1999c) showed that for some clay minerals, the difference between structures of outer and core layers may have significant influence on the diffraction effects. These authors developed a special mathematical formalism to simulate diffraction effects from periodic and mixed-layer structures having different outer surface layers. In particular, simulation of XRD patterns shows that chlorite crystal models consisting of the same amount of 2:1 layers but terminated by either $2: 1$ or brucite-like layers have significantly different distributions of basal reflection intensities, which, in turn, differ from the distribution of basal reflection intensities for periodic chlorite crystals containing the same amount of 2:1 layers and terminating with a brucite-like layer on the one side of the crystals and with a 2:1 layer on the other side. In fact, relative intensities of 001 reflections have maximum and minimum values when chlorite crystals of a given composition are terminated on both sides either by brucite-like or by 2:1 layers. Similar diffraction effects were observed for mixedlayer chlorite-smectites having different outer surface layers. It was shown that for investigated chlorite samples the best fit between experimental and calculated XRD patterns was obtained for chlorite crystallites terminated by brucite layers on both sides.

\section{Mixed-layer minerals consisting of incommensurate layers}

Depending on the dimensions and shape of unit cells of different layer types, mixed-layer structures can be grouped in three categories: (1) structures with identical two-dimensional unit cells in different layer types. Combination with a similar anion structure of the basal surface in different layers ensures stable interlayer bonds in these minerals; (2) commensurate structures in which the unit cell of one layer type is a subcell of the other type layer unit cell (e.g. chlorite); and (3) incommensurate structures, or structures whose layers have their own two-dimensional periodicities without rational relation between the cell parameters in alternating layers (Drits, 1987b; Organova, 1989; Makovicky \& Hyde, 1992). Incommensurability may have different nature: the alternating layers may either differ in structure, or having a similar structure, differ in the cation and/ or anion composition. Incommensurate structures may have either ordered or random interstratification of layer types.

Selected area electron diffraction (SAED) is especially powerful for revealing mixed-layer minerals consisting of incommensurate layers (Drits, 1987b, 1997). The combination of SAED and energy dispersion analysis (EDA) widely extends the possibilities of the structural investigation of fine-dispersed minerals, especially in the case of polymineral samples. These opportunities are illustrated by the results of the structural study of asbolanes, a very peculiar group of phyllomanganates, containing 'alien' cations (Chukhrov et al., 1982, 1989; Manceau et al., 1982; Drits, 1987b).

It was found that asbolanes consist of two regularly interstratified incommensurate layer types having different cation compositions. Due to different lateral dimensions of the layer types, the asbolane structure can be described on the basis of two or even three sub-lattices having different $a, b$ parameters but identical periodicity along the $c$ axis. A very peculiar feature of asbolane structures is that the layers of one type are two-dimensionally continuous within CSDs whereas the layers of the other type have island-like structure.

EDA has shown the existence of several asbolane varieties differing in chemical composition. Application of X-ray absorbtion spectroscopy (XANES and EXAFS) has shown that cations of different nature and valency have a strong tendency to segregation (Manceau et al., 1992). For example, in the so-called Co-Ni asbolane, each layer type contains only cations of a given type, and octahedral layers $\mathrm{MnO}_{2}, \mathrm{Ni}(\mathrm{OH})_{2}$ and $\mathrm{CoO}(\mathrm{OH})$ coexist within the same crystals. Among the other asbolane varieties, there is $\mathrm{Ni}$-asbolane, in which $\mathrm{Mn}^{4+}$ octahedral layers alternate with island-like Ni-containing brucite-like layers. A very exotic 
example is pure manganese asbolane where $\mathrm{Mn}$ is present in three incommensurate layers as tetra-, triand divalent cations.

Using SAED and EDA techniques, a mixed-layer incommensurate asbolane-buserite was found among oceanic Fe-Mn nodules (Chukhrov et al., 1989). The buserite structure consists of octahedral $\mathrm{Mn}^{4+}$ layers separated by exchangeable cations and water molecules and has a period along the $c$ axis equal to $10 \AA$. Irregular interstratification of $10 \AA$ buserite and $10 \AA$ asbolane layers creates $10 \AA$ pseudo-periodicity along the $c$ axis. Therefore the XRD patterns of asbolane-buserite in the air-dried state are similar to those of poorly crystallized asbolanes, buserites and todorokites. However, under the vacuum conditions of an electron microscope, the $10 \AA$ buserite layers are transformed into $7 \AA$ birnessite layers and the mineral is transformed into a mixed-layer asbolane-birnessite with the random interstratification of incommensurate $10 \AA$ and $7 \AA$ packets. This leads to a nonrational series of basal reflections which is an indication of the interstratification (Chukhrov et al., 1989).

Application of SAED also revealed very peculiar mixed-layer minerals consisting of incommensurate brucite and sulphide layers (tochilinite, $3 R$ and $1 T$ valleriites), as well as of brucite, sulphide and silicate layers (Drits, 1987b; Organova, 1989).

\section{Mixed-layer structures in which the layer thickness of one of the layers is a multiple value of the other layer thickness}

A particular case of such a structure is interstratification of $14 \AA$ chlorite and $7 \AA$ serpentine layers (Reynolds, 1988). Figure 1 shows that even $5 \%$ of $7 \AA$ layers in a mixed-layer chloriteserpentine structure significantly decreases the intensities of odd reflections and increases their width in comparison with those of even reflections (Ivanovskaya et al., 1999; Drits et al., 2001). This conclusion is consistent with results obtained by Ryan and Reynolds (1997) for interstratified chlorite-serpentines. On the contrary, when the amount of $7 \AA$ layers increases up to $70-75 \%$ the diffraction effects turn out to be practically insensitive to the presence of $25-30 \%$ of $14 \AA$ layers (Fig. 2), so that the chlorite component cannot practically be detected by XRD in this case. Its presence can be determined more effectively by HRTEM (Bailey et al., 1995).
Interstratification of the layers having similar but not identical layer thicknesses

A family of mixed-layer structures in which layers and/or interlayers differ from each other in occupancy and distribution of isomorphous cations is widely spread among natural and synthetic layer compounds. In particular, mica interlayers may be occupied by $\mathrm{K}$ and $\mathrm{Na}$ or $\mathrm{K}$ and $\mathrm{NH}_{4}$. The problem is to determine orderdisorder in the distribution of these cations because they may have different distributions when interlayers have the same average composition. For example, $\mathrm{K}$ and $\mathrm{NH}_{4}$ can be distributed among different interlayers according to one of the two limiting cases. In the first one, $\mathrm{K}$ and $\mathrm{NH}_{4}$ are distributed homogeneously in each interlayer. In the second model each interlayer contains either $\mathrm{K}$ or $\mathrm{NH}_{4}$. In other words, this model represents a mixed-layer structure in which K-bearing $9.98 \AA$ illite and $\mathrm{NH}_{4}$-bearing $10.33 \AA$ tobelite layers are interstratified. Drits et al. (1997b) worked out a special technique to determine the average $\mathrm{NH}_{4}$ content, as well as the distribution of $\mathrm{NH}_{4}$ and $\mathrm{K}$ in illite and I-S containing fixed $\mathrm{NH}_{4}$. The main problem in determination of fixed $\mathrm{NH}_{4}$ in I-S by diffraction methods is that different proportions and distribution of the layer types modify positions, intensities and profiles of basal reflections much stronger than the presence of $\mathrm{NH}_{4}$. It was shown that the sensitivity of diffraction effects to the presence of $\mathrm{NH}_{4}$ cations can be significantly increased if I-S are saturated by $\mathrm{K}$, subjected to several cycles of wetting and drying, and dehydrated. After such treatment, K-bearing expandable layers collapse to $9.98 \AA$ and the treated I-S will have similar periodicity. It was found that the positions of the basal reflections of the treated I-S can be used to determine the average content of fixed $\mathrm{NH}_{4}$, whereas comparison of widths of the basal reflections with different $l$ provides quantitative information about the distribution of $\mathrm{K}$ and $\mathrm{NH}_{4}$ over different interlayers. Note that certain precautions should be taken in the application of this approach to I-S containing $>50 \%$ of expandable interlayers. The reason is that even after saturation of these interlayers by $\mathrm{K}$, the effect of the layer fluctuations may be significant in disturbing the relationship between the basal reflections' widths due to the interstratification of $\mathrm{K}$ - and $\mathrm{NH}_{4}$ - bearing interlayers. 


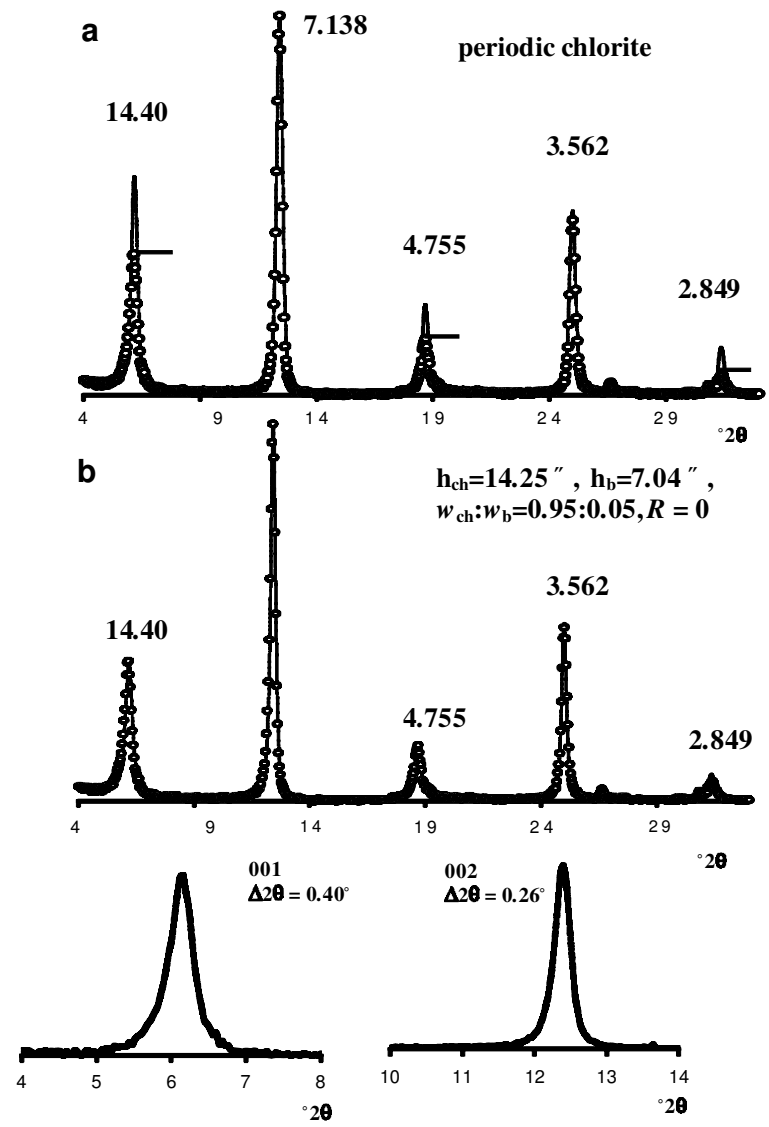

FIG. 1. Comparison of the experimental XRD pattern (dotted line) with those calculated for a periodic chlorite structure (a) and a mixed-layer chlorite-serpentine (b). The lower two maxima show different widths of the experimental 001 and 002 reflections.

Application of the ${ }^{27} \mathrm{Al}$ and ${ }^{29} \mathrm{Si}$ magic-angle spinning nuclear magnetic resonance (MAS $N M R$ ) for the crystal chemical study of heterogeneous clay minerals

${ }^{27} \mathrm{Al}$ MAS NMR spectroscopy determines very accurate ${ }^{[4]} \mathrm{Al} /{ }^{[6]} \mathrm{Al}$ ratios and ${ }^{29} \mathrm{Si}$ MAS NMR may be used for fitting to obtain ${ }^{[4]} \mathrm{Al} / \mathrm{Si}$ ratios. These data are usually used for the study of the shortrange order in distribution of ${ }^{[4]} \mathrm{Al}$ and $\mathrm{Si}$ in tetrahedral sheets of various layer silicates (see below). However, the data obtained by the MAS NMR method can be used to determine crystalchemical features of mixed-layer minerals having complex structures. In particular, Lindgreen et al. (2002) developed a methodology by which the ${ }^{[4]} \mathrm{Al} /{ }^{[6]} \mathrm{Al}$ ratios, in combination with the results of the chemical analysis and the multispecimen

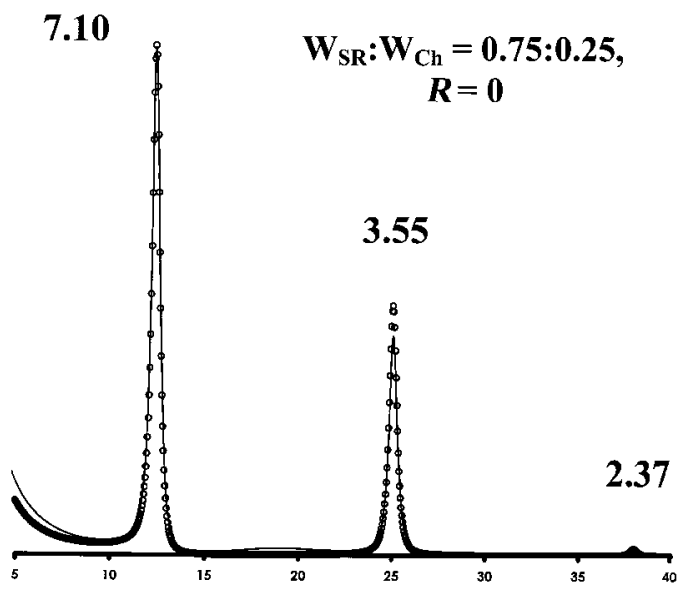

FIG. 2. Comparison of XRD patterns calculated for a periodic $7 \AA$ serpentine (solid line) and mixed-layer chlorite-serpentine containing $25 \%$ of chlorite layers. 
method, allowed determination of reliable averaged cation composition in octahedral and tetrahedral sheets of 2:1 layers and in brucite-like interlayers sheets in the three-component illite-smectite-ditrioctahedral chlorite (tosudite) structures found in Cretaceous-Tertiary chalk. Coexistence of I-S with kaolinite or/and chlorite is typical for many natural clays. Lindgreen et al. (2000) and Drits et al. (2002a,b) showed how the ${ }^{27} \mathrm{Al}$ and ${ }^{29} \mathrm{Si}$ spectra can be used for a quantitative analysis of such mixtures and accurate determination of structural formulae of the I-S.

\section{Application of the multispecimen technique}

To apply this technique, a mixed-layer sample is saturated by different interlayer cations $(\mathrm{Ca}, \mathrm{Mg}$ or $\mathrm{Na}$ ) and XRD patterns for each specimen are recorded in identical experimental conditions in air-dry and glycolated states. A structural model for the studied mineral can be considered as corresponding to the actual structure if the experimental XRD patterns obtained from different specimens of the sample are successfully simulated using the same set of probability parameters describing content and distribution of the interstratified layer types. If a sample is a mixture of periodic, along $c$ axis, and mixed-layer phases then simulation of the XRD patterns includes two steps. The first uses a trial-and-error approach to determine structural and probabilities parameters that provide a satisfactory agreement between experimental and calculated positions, intensities and profiles for each phase of a sample (Drits et al., 1997a; Sakharov et al., 1999a,b). In the second step, structural and probability parameters describing each phase are fixed, and the modified program of Drits and Sakharov (1976) automatically seeks the best agreement (minimum $R$-factor) between experimental and calculated XRD patterns by varying the contents of the phases in a sample. As a result, both the contents of each phase and the structural and probability parameters for the mixed-layer varieties are obtained (Drits et al., 2002a; Lindgreen et al., 2002).

The efficiency of the method is illustrated by results obtained in the structural study of I-S from oil-source Upper Jurassic shales from the North Sea (Drits et al., 1997a, 2002b). The problem was to answer two questions: first, what are the crystalchemical features of I-S formed during diagenesis in oil-source shales and, second, what is the structural mechanism for the diagenetic evolution of these minerals? Generally, in oil-source rocks of sedimentary basins, oil generation takes place simultaneously with diagenetic transformation of I-S. A link between these two reactions was demonstrated: $\mathrm{NH}_{3}$ released during maximum oil generation is fixed as $\mathrm{NH}_{4}$ cations in the $\mathrm{NH}_{4}$ bearing mica or tobelite layers formed from smectite or vermiculite layers of the I-S. This reaction leads to formation of four-component illitetobelite-smectite-vermiculite (I-T-S-V) minerals in a diagenetic interval called the 'tobelitizationwindow' (Drits et al., 2002b). A remarkable crystal-chemical feature of the representative collection of samples studied was the fact that the proportion of K-bearing illite layers, as well as the amount of fixed $\mathrm{K}$ cations per $\mathrm{O}_{10}(\mathrm{OH})_{2}$ in the studied mixed-layer minerals were constant and equal to $(65 \pm 5) \%$ and $(0.38 \pm 0.02)$ cations, respectively, independent of sample location, depth and degree of diagenetic transformation. On the contrary, the amount of tobelite layers and fixed $\mathrm{NH}_{4}$ cations increases with diagenesis.

Several important conclusions concerning the structural mechanism of I-S diagenetic evolution and the initial origin of I-S follow from the crystal chemical features of I-T-S-V.

First, in oil-source Upper Jurassic shales, diagenesis is accompanied not by smectite illitization, as was generally accepted, but by smectite tobelitization. Indeed, the evolution of I-S is accompanied by selective sorbtion and fixation of $\mathrm{NH}_{4}$ cations in former smectite and vermiculite interlayers.

Second, the constant values for the illite layers and the number of $\mathrm{K}$ cations can be considered as evidence of solid-phase transformation of the I-T-S$\mathrm{V}$ structure. Indeed any other mechanisms would have destroyed this constancy. The conclusion concerning the structural mechanism of I-T-S-V formation is confirmed by the same shape and size of clay particles for all studied samples. The fact that the amount of illite layers does not depend on location and degree of diagenesis of the mixedlayer minerals may be considered as evidence of a common parent detrital material.

Along with the North Sea samples, I-S minerals from Cambrian Baltic shales have been studied, and formation of tobelite layers has been also found (Lindgreen et al., 2000). Therefore, it is quite plausible that tobelitization of I-S and I-S-V in diagenetically altered oil-producing sedimentary 
basins is a common phenomenon and the presence of tobelite layers in I-T-S or I-T-S-V in oil-source rocks may be considered as independent evidence for oil generation even after migration or thermal decomposition of the oil.

The multispecimen method in combination with chemical analysis and ${ }^{27} \mathrm{Al}$ MAS-NMR spectroscopy was applied to the study of the structure and diagenetic transformation of illite-containing mixedlayer minerals from North Sea Cretaceous-Tertiary clays (Lindgreen et al., 2002). It was shown for the first time that, in contrast to burial diagenetic I-S transformation, early diagenesis of North Sea oil field and Danish outcrop chalk is accompanied by a solid-state process during which $\mathrm{Mg}$ cations were fixed in former smectite interlayers of the I-S forming brucite-like sheets and, as a result, an illitesmectite-ditrioctahedral chlorite (tosudite) structure was formed. During later diagenesis, a neoformation of a tosudite and trioctahedral chloriteberthierine took place.

Thus the new methodologies have revealed new diversity in structural and chemical heterogeneity of MLM, provided new insight into the structural mechanism of I-S evolution during oil generation and chalk rock formation, and discovered new natural processes.

\section{Determination of the actual mutual layer arrangements in layer silicate structures}

As in the case of irregular mixed-layer minerals, X-ray structural study of stacking faults in layer minerals consisting of identical layers is based on a trial-and-error approach (Drits \& Tchoubar, 1990; Reynolds, 1993). The nature of stacking faults depends on the structure of a mineral under study. For example, in the case of micas, stacking faults, as a rule, are confined to layer rotations, whereas in the case of chlorite, serpentine and kaolin minerals stacking faults may result from layer displacements, rotations and reflection operations. As a consequence, determination of the nature of stacking faults in these minerals by XRD is a complex problem. Investigation of stacking faults in kaolin structures is demonstrative in this respect. Different models of stacking faults based on the idealized kaolinite structure have been proposed: $\pm b / 3$ layer displacements, $\pm 120^{\circ}$ layer rotations, octahedral vacancy displacements. Bookin et al. (1989) showed that these models do not account for the intensity distribution in the experimental XRD patterns. These authors achieved significant progress in the solution of the problem when the actual structural features of kaolinite and dickite layers and their interlayer displacements were taken into account. According to Bookin et al. (1989), the interstratification of right-hand and left-hand enantiomorphic kaolinite layers having equivalent unit cells defines the most probable stacking faults. In terms of their models, the possibility of a continuous series between kaolinite and dickite through 'dickite'-type faults seems hardly probable. Plançon et al. (1989), using simulation of diffraction effects, confirmed the validity of the models described by Bookin et al. (1989). In addition, it was shown that many samples are mixtures of two kaolinite phases having either high or low concentrations of stacking faults. This conclusion was confirmed experimentally by Bish \& Chipera (1998).

Zvyagin \& Drits (1996) considered, in the most general form, the theoretically possible layer stackings which may lead to stacking faults in the real kaolinite structure. To do this, the authors took into account the actual distortions of inter- and intralayer displacements of adjacent octahedral and tetrahedral sheets, deviations of unit-cell parameters and normal projections of the $c$ axis on the $a b$ plane observed in periodic structures of dickite, kaolinite and nacrite. It was shown that along with displacements, rotations and reflection operations, analysis of deviations of the actual structure from the idealized one has key importance not only for the understanding, but also for the explanation of the formation of different polytypes, stacking faults, polytype transitions in the kaolin structures, as well as other minerals.

Significant progress in determination of the layerstacking sequences in layer silicates has been obtained by HRTEM (Banfield \& Murakami, 1998; Kogure \& Banfield, 1998; Kogure \& Nespolo, 1999a,b, 2001; Kogure et al., 2002). Conventionally, HRTEM images of layer silicates are obtained along [100], [110] or [1피 because images along [010], [310] or [31̄0] require higher resolution. As a result, stacking sequences containing $(2 n+1) 60^{\circ}$ layer rotations and welldefined stacking faults along the $a$ axis cannot be determined by HRTEM. The remarkable methodological achievement of Kogure and his coauthors is that HRTEM images are obtained along two important crystallographic directions of the same 
part of the crystal, for example, along [100] and [310]. This approach determines unambiguously individual polytype modifications, as well as translational and rotational stacking faults disturbing the periodicity of layer sequences. For example, by viewing along the [010], [310] and [310] directions the six groups of the standard polytypes of chlorite and the four groups of the standard polytypes of serpentines can be distinguished. Images recorded along the [100], [110] and [110] allow determination of the polytype in each group.

Using this approach, Kogure \& Nespolo (1999a,b, 2001) and Kogure et al. (2001, 2002) discovered the nature of stacking faults in the actual crystal structure of Mg-rich annite, oxybiotite and two cronstedtite varieties. For example, Kogure and Nespolo (1999b) obtained HRTEM images from a Ti-containing Mg-rich annite crystal along [110] and [010]. Analysis of these images allowed determination of the layer stacking sequence containing more than 100 layers in which layers in layer pairs were rotated with respect to each other by $\pm 60^{\circ}, \pm 120^{\circ}$ and $180^{\circ}$, and sometimes were parallel to each other. Distribution of these layer pairs shows that fragments of $1 M, 2 M_{1}, 2 M_{2}$ and $2 O$ polytypes coexist in the mica crystal. Analysis of HRTEM images of crondstedtite from Lostwithiel, England recorded along two directions rotated with respect to each other by $30^{\circ}$ shows that thin fragments of the polytype groups $\mathrm{A}$ and $\mathrm{C}$ are interstratified in the crystal of this mineral. This observation shows that previous suggestions that polytype modifications of different groups do not occur together are not correct.

Very peculiar planar defects were observed in oxybiotite from the Ruiz Peak ash flow, New Mexico (Kogure \& Nespolo, 2001). One of these kinds of defects is represented by tetrahedral double layers as in the hexacelsian $\left(\mathrm{BaAl}_{2} \mathrm{Si}_{2} \mathrm{O}_{8}\right)$ type structure, whereas the other kind corresponds to a set of brucite-like octahedral layers parallel to a (001) plane. In contrast to 2:1 layers, in the tetrahedral double layers, octahedral sheets are absent and the upper and lower tetrahedral sheets share their apical oxygen atoms.

One of the main advantages of the approach in which images are recorded in two crystallographic directions is that it provides a new insight into the structural mechanism of phase transformations (Banfield \& Murakami, 1998; Murakami et al., 1999; Schmidt \& Livi, 1999). For example, investigation of the chloritization mechanism of biotite in a granitic rock showed that, typically, two biotite layers transform to one chlorite layer. Less commonly, mica interlayers are replaced by brucitelike sheets without distortion of adjacent 2:1 layers. It was found that the chlorite polytype in biotitechlorite intergrowths is represented by $I I b b$ or, more seldom, interstratification of $I b b, I a b, I I a b$ and $I I b b$ varieties (Kogure \& Banfield, 2000).

Murakami et al. (1999) showed that the saponiteto-chlorite reaction proceeds via corrensite and, thus, includes two stages: first, from saponite to corrensite, and then from corrensite to chlorite. Both stages occur though dissolution and precipitation. These data show that corrensite, as well as chlorite and smectite, should be considered as independent structural units participating in the formation of mixed-layer chlorite-corrensite-smectites. Previously these suppositions were made by Beaufort et al. (1997).

Even these several examples demonstrate the great contribution of HRTEM to the study of the structural and chemical heterogeneity of minerals. However, in some cases, opportunities for this method are limited. For example, this is probably the case of dioctahedral micas and I-S, in which structural heterogeneity is associated with interstratification of trans-vacant $(t v)$ and cis-vacant $(c v)$ $2: 1$ layers. It is more effective to study this heterogeneity by diffraction methods and thermal analysis.

Coexistence of $t v$ and $c v$ layers in I-S; $c v$ containing I-S - a possible indicator of their initial volcanic origin

Tsipursky \& Drits (1984) showed that in the 2:1 layers of smectites, as a rule, one of two symmetrically independent cis-octahedra is vacant, whereas illite normally has $t v$ layers. Accordingly, formation of illite layers from smectite layers during smectite illitization should lead to an increase in proportion of $t v 2: 1$ layers. Coexistence of $c v$ and $t v$ layers in I-S formed in volcanic and sedimentary rocks was described recently in many papers (McCarty \& Reynolds, 1995, 2001; Drits et al., 1996, 2002a; Altaner \& Ylagan, 1997; Cuadros \& Altaner, 1998a; Ylagan et al., 2000; Lindgreen et al., 2000; Lindgreen \& Surlyk, 2000). However, physicochemical conditions, structural mechanisms of formation and other factors responsible for interstratification of $c v$ and 
tv layers in I-S remain poorly understood. Drits et al. (1996), Cuadros and Altaner (1998b) and Ylagan et al. (2000), in bentonites and hydrothermally alerted pyroclastic material, found that an increase in illite layers is a accompanied by increasing $t v$ layers. On the contrary, McCarty and Reynolds $(1995,2001)$ showed that in K-bentonite from the Appalachian Basin the amounts of $c v$ layers in I-S do not correlate with expandability and rotational disorder. Moreover, interstratification of $t v$ and $c v$ layers may occur even in non-swelling illites. For example, an illite sample from the Amethyst Vein System, Colorado, initially described as $3 T$ illite (Horton, 1983) in fact, contains almost equal amounts of $t v$ and $c v$ layers (unpublished data).

There are contradictory data concerning the relationship between cation composition of $2: 1$ layers and distribution of octahedral cations over trans- and cis-sites. According to Tsipursky \& Drits (1984), in dioctahedral smectites this distribution depends on the degree of $\mathrm{Al}$ for $\mathrm{Si}$ substitution and the homogeneity of octahedral cation composition. According to their classification, beidellites and nontronites are trans-vacant, whereas montmorillonites and some Al-rich smectites, in which the layer negative charge is located in both octahedral and tetrahedral sheets of the 2:1 layers, are cis-vacant. Sainz-Diaz et al. (2001b) carried out theoretical modelling of $c v$ and $t v$ sheets of illites and smectites of various chemical compositions using empirical interatomic potentials. They concluded that, although the energy difference between the $t v$ and $c v$ layers is small, the $c v$ layers are more stable when the cation composition of the layer is more smectitic. These results are consistent with recent experimental data showing that most smectites are cis-vacant (Drits et al., 1996, 1998b; Cuadros \& Altaner, 1998a,b; Ylagan et al., 2000; Cuadros, 2002). On the contrary, according to McCarty and Reynolds (2001) the amount of $c v$ layers in the I-S increases with tetrahedral $\mathrm{Al}$ and decreases with octahedral $\mathrm{Mg}$ and $\mathrm{Fe}$ content, i.e. when the $c v$ layer composition is more illitic. These observations are consistent with the fact that most structurally well ordered $c v \quad 1 M$ illites contain 2:1 layers consisting mostly of $\mathrm{Al}$ and $\mathrm{Si}$ (Zvyagin et al., 1985; Drits et al., 1993; Lanson et al., 1996; Reynolds \& Thomson, 1993). Thus $c v$ layers should be stable in smectites, for which the layer negative charge is mostly located in the octahedral sheets of the 2:1 layer, and in illites, for which this charge is located largely in the tetrahedral sheets.
One of the plausible explanations for this tendency may be related to different interlayer structures of $1 M$ illites consisting either of $t v$ or $c v$ layers. In the case of $t v 1 M$ illite the upper and lower tetrahedral sheets of the 2:1 layer are related by a mirror plane parallel to the $a c$ plane. In the case of $c v 1 M$ illite, these sheets are rotated with respect to each other by $120^{\circ}$ (Drits et al., 1984). It is well known that in dioctahedral micas the interlayer cavity has a slightly irregular form due to tetrahedral tilt and basal oxygen surface corrugation (Bailey, 1984). In the interlayer cavity of tv $1 M$ illite, each $\mathrm{K}$ cation is located in a distorted octahedron in which two basal oxygen atoms of adjacent layers related by a space diagonal passing through the mirror plane are shifted in opposite directions inside the layers. Therefore even in $t v 1 M$ illite having phengitic cation composition, the distances between the $\mathrm{K}$ and two 'depressed' basal oxygen atoms are greater than those with the other four 'inner' oxygen atoms (Drits, 1987b). In contrast, the interlayer $\mathrm{K}$ in $c v 1 M$ illite has an environment which is quite similar to that of interlayer $\mathrm{K}$ in $2 M_{1}$ muscovite because the upper and lower tetrahedral sheets in each $c v$ 2:1 layer are rotated with respect to each other by $120^{\circ}$. Therefore a very small displacement of interlayer $\mathrm{K}$ along the two-fold axis toward the nearest vacant octahedral site significantly equalizes the lengths of the $\mathrm{K}-\mathrm{O}$ bonds. The hypothesis that almost $(\mathrm{Mg}, \mathrm{Fe})$-free illites consisting of $c v$ layers are more preferable to $t v 1 M$ illites having the same cation composition can be supported at least by two experimental observations.

Drits et al. (1993) described an association of periodic $t v$ and $c v 1 M$ illites from hydrothermal alterations around uranium deposits located in the Athabasca basement (Canada). It was shown that $c v$ $1 M$ illites in coarser size fractiona are significantly more abundant than in the fine fraction. Lanson et al. (1996) studied kaolin illitization processes during burial diagenesis of Rotliegend sandstones and observed the coexistence of $t v$ and $c v 1 M$ illites, as well as the increase in the abundance of cv $1 M$ illite with temperature and depth. Both of these facts can be considered as evidence that under low-temperature diagenesis and hydrothermal conditions, Al-rich $c v 1 M$ illite is more stable than its $t v 1 M$ polymorph.

According to the literature, structural mechanisms of formation of I-S containing interstratified $t v$ and $c v$ layers may be different. Cuadros and Altaner 
(1998b) showed that smectite illitization in the bentonite I-S samples proceeds through the solidstate transformation (SST) mechanism. In this case, transformation of $c v$ into $t v$ layers occurs within I-S crystallites preserving significant morphological changes of the I-S particles. Evolution of $c v / t v$ ratios in I-S during hydrothermal transformation of rhyolitic volcanoclastic from Dolna Ves, Slovakia, showed that the reaction was a SST of smectite to illite layers up to $50 \%$ illite layers. At this stage, all 2:1 layers have $c v$ sites, whereas further increase in the amount of illite layers up to $90 \%$ was accompanied by a dissolution-reprecipitation process, during which $c v$ layers were replaced by tv 2:1 layers (Drits et al., 1996).

The I-S from a hydrothermally altered rhyolitic hyaloclastite from Ponza Island, Italy were represented by a full series from pure $c v$ smectite to almost pure $t v$ illite through intermediate phases consisting of interstratified $c v$ and $t v$ layers (Ylagan et al., 2000). On the basis of abrupt changes in morphology, smectite illitization on Ponza involved a dissolution and recrystallization mechanism with multiple stages of nucleation and crystal growth. This means that synthesis of the I-S included simultaneous growth of $t v$ and $c v$ layers in each individual I-S crystal.

It is well known that the $c v$ smectites are primary products of transformed volcanoclastic rocks of rhyolitic composition. Therefore, as a rule, I-S consisting of $t v$ and $c v$ layers are associated with volcanic materials (Drits, 1987a,b; McCarty \& Reynolds, 1995, 2001; Drits et al., 1996, 1998b, 2002a; Cuadros \& Altaner, 1998b; Ylagan et al., 2000). Thus, one may assume that structures consisting of $t v$ and $c v$ layers originate from altered volcanic material (Drits et al., 1998b).

In contrast, I-S primarily formed from weathered illite typically consist of $t v 2: 1$ layers independent of the content of I and S layers, such as found for I-S from the Upper Jurassic oil-source rocks (Drits et al., 1997a). Investigation of I-S from black Cambrian shales (Baltic area) showed that samples having a small degree of diagenetic transformation consist of a physical mixture of detrital illite and I-S composed of $t v$ and $c v$ layers (Lindgreen et al., 2000). It was concluded that the parent material of the I-S was volcanic.

Investigation of I-S in one Upper Jurassic Kimmeridgian mudstone core from East Greenland showed that the I-S samples located at different levels in the core differ from each other in the amounts of $c v$ layers (Drits et al., 2002a). In particular, I-S at the bottom $(37 \mathrm{~m})$ and in the middle $(13 \mathrm{~m})$ of the core contained $60-80 \% \mathrm{cv}$ layers and $60 \%$ of expandable layers, whereas in I-S located at $12.4 \mathrm{~m}$ and $17.7 \mathrm{~m}$ depth, tv layers prevail $(\sim 80 \%)$ although content of expandable layers in their structure was still high (45\%). It was calculated that I-S with a large $c v$ layer content were formed from $c v$ smectite which is probably of volcanic origin. Thus these findings of I-S reflect episodes of volcanic activity during Kimmeridgian time, as suggested by Lindgreen and Surlyk (2000).

Despite some progress in the study of I-S, further investigations are required in order to clearly determine the crystal chemical nature of I-S of different origins, the mechanisms and dynamics in their structural transformations and the factors controlling the coexistence of 2:1 layers differing in cation distribution.

Diffraction methods for determination of $t v$ and $c v$ layers in illite and I-S. Generalization of Méring's rules

Reynolds (1992) showed that there is no threedimensional coherence across the expandable interfaces that separate stacks of thin illite fundamental particles (Nadeau et al., 1984). Therefore, a randomly oriented specimen of I-S diffracts in three dimensions like a randomly oriented set of thin illite crystals.

Different distributions of octahedral cations over trans- and cis-sites in 2:1 layers are accompanied by specific distortions of cis- and trans-octahedra (Drits et al., 1984, 1995). In a $t v$ layer, the centre of the ditrigonal ring of the upper tetrahedral sheet is shifted from the centre of the lower tetrahedral sheet in projection on the $a b$ plane by more than the ideal $-a / 3$ value. As a result, in $t v 1 M$ illites, projection of the $c$ axis on the $a b$ plane $(c \cos \beta)$ is equal to $\mathrm{T}_{t v}=-(0.38 a \div 0.40 a)$ depending on the octahedral cation composition of the 2:1 layers. In particular, it was found that $\mathrm{T}_{t v}$ values vary from $-0.400 a$ to $-0.390 a$ for almost Fe,Mg-free illites and from $-0.386 a$ to $-0.383 a$ for illites having phengite cation composition (Bailey, 1984; Drits et $a l ., 1984,1993)$. In the $c v$ layer this shift is $<-a / 3$, and in $c v 1 M$ illites $\mathrm{T}_{c v}=c \cos \beta=-(0.30-0.32) a$ (Drits et al., 1984, 1993; Tsipursky \& Drits, 1984; Zvyagin et al., 1985; Reynolds \& Thomson, 1993). Thus, interstratification of $t v$ and $c v$ layers is associated with interstratification of two different 
translations and is accompanied by significant variations of positions, intensities, and profiles of non-basal reflections in the powder XRD patterns.

There are two diffraction methods for the determination of coexistent $t v$ and $c v$ layers in mica structures which will be considered below in succession. One of them is based on calculation of XRD patterns from different structural models containing interstratified $t v$ and $c v$ layers, as well as rotational and translational stacking faults (Drits et al., 1984; Reynolds, 1993). Atomic coordinates for unit cells for $t v$ and $c v 1 M$ illites used in these calculations were obtained by Drits et al. (1984). Examples of the application of this approach are given by Reynolds (1993), McCarty \& Reynolds (1995, 2001), Ylagan et al. (2000).

The structural study of smectites is a difficult task because of their turbostratic structure. However, even for these minerals, essential information concerning the distribution of octahedral cations over trans and cis sites can be obtained by simulation of diffraction effects. Indeed, Drits $e t$ al. (1984) showed that the intensity of the twodimensional 02-11 band for dioctahedral micas and dehydrated smectites is constant if their layers are either $t v$ or $c v$. In contrast, if octahedral cations are randomly distributed over trans and cis sites within the same layer, the intensity of the $02-11$ band decreases significantly. At the same time, the intensity of the $20-13$ band does not depend on the cation distribution. Therefore the intensity ratio of the $02-11$ and $20-13$ bands is sensitive to the distribution of octahedral cations between cis and trans sites within the same octahedral sheet.

Taking into account this result, Manceau et al. (2000) calculated the intensity of the 02-11 and 20-13 bands for different occupancies of trans and cis sites and compared them with the experimental patterns of four different nontronites having turbostratic structures. Best fits were obtained by assuming $100 \%$ occupancy of cis-sites in the nontronite samples within the detection limit of $5 \%$ of total $\mathrm{Fe}$

The scientific significance of this result arises from the fact that the actual occupancy of trans and cis sites is important for reliable interpretation of magnetic properties of nontronites. As a matter of fact, oblique texture electron diffraction and XRD showed that nontronites are trans-vacant (Besson et al., 1983a; Tsipursky \& Drits, 1984). However, the accuracy of these techniques was not sufficient to exclude completely the presence of some $\mathrm{Fe}^{3+}$ in trans-octahedra. Therefore, to explain the non-ideal antiferromagnetic behaviour of SWa-1 nontronite at low temperature, Lear and Stucki (1990) assumed that $\sim 13 \%$ of trans-sites were occupied by $\mathrm{Fe}^{3+}$.

Another way to determine the distribution of octahedral cations over trans and cis sites in a smectite structure is related to an artificial increase of its 3D order. To do this, smectite samples are saturated with large anhydrous $\mathrm{K}$ or Cs cations, and subjected to wetting-and-drying cycles, and then dehydrated by heating and using vacuum (Besson $e t$ al., 1983b; Tsipursky \& Drits, 1984; Drits et al., 1996; Cuadros, 2002).

Powder XRD patterns of the treated smectites contain significant intensity modulation in the diagnostic region of $02 l$ and $11 l$ reflections. Recently, Cuadros (2002) studied Cs-saturated smectites of different cation compositions and using simulation of the experimental XRD patterns. He showed that the studied nontronite samples consist of $t v$ layers whereas the montmorillonite samples are cis vacant.

The second method for the determination of coexistent $t v$ and $c v$ layer content is based on the ability of XRD to average the structural parameters of a defective sample (Drits \& McCarty, 1996). For illites consisting of $t v$ and $c v$ layers, diffraction should average interstratified interlayer translations. This means that a given interstratified structure should be characterized by a statistically weighted interlayer displacement equal to $\mathrm{T}_{e f}=\mathrm{W}_{c v} \mathrm{~T}_{c v}+$ $\mathrm{W}_{t v} \mathrm{~T}_{t v}$ where $\mathrm{W}_{c v}$ and $\mathrm{W}_{t v}$ are the occurrence probabilities for $c v$ and $t v$ layers; $\mathrm{T}_{t v}$ and $\mathrm{T}_{c v}$ are the projections of the $c$ axis on the $a b$ plane for $t v 1 M$ and $c v 1 M$ illites, respectively. Taking into account that $\mathrm{W}_{c v}+\mathrm{W}_{t v}=1$ the equation for $\mathrm{T}_{e f}$ can be transformed to:

$\mathrm{W}_{c v}=\left(\mathrm{T}_{t v}-\mathrm{T}_{e f}\right) /\left(\mathrm{T}_{t v}-\mathrm{T}_{c v}\right)$. Thus, the $c v$ and $t v$ layer contents can be calculated because $\mathrm{T}_{t v}$ and $\mathrm{T}_{c v}$ are known for illite of a given cation composition (Drits et al., 1993, 1995) and $\mathrm{T}_{e f}$ can be calculated using experimental values of $d(11 l)$ and the formulae given by Drits \& McCarty (1996).

There is a simple and clear way to interpret the nature of diffraction effects from structures consisting of interstratified $c v$ and $t v$ layers. Figure 3 shows XRD patterns corresponding to periodic $t v$ and $c v 1 M$ micas, respectively. In these patterns, reflections having the same $h k l$ indices have different intensities and, in addition, $11 l$ reflections having the same 1 values have different positions because of different $c \cos \beta$ values. The 


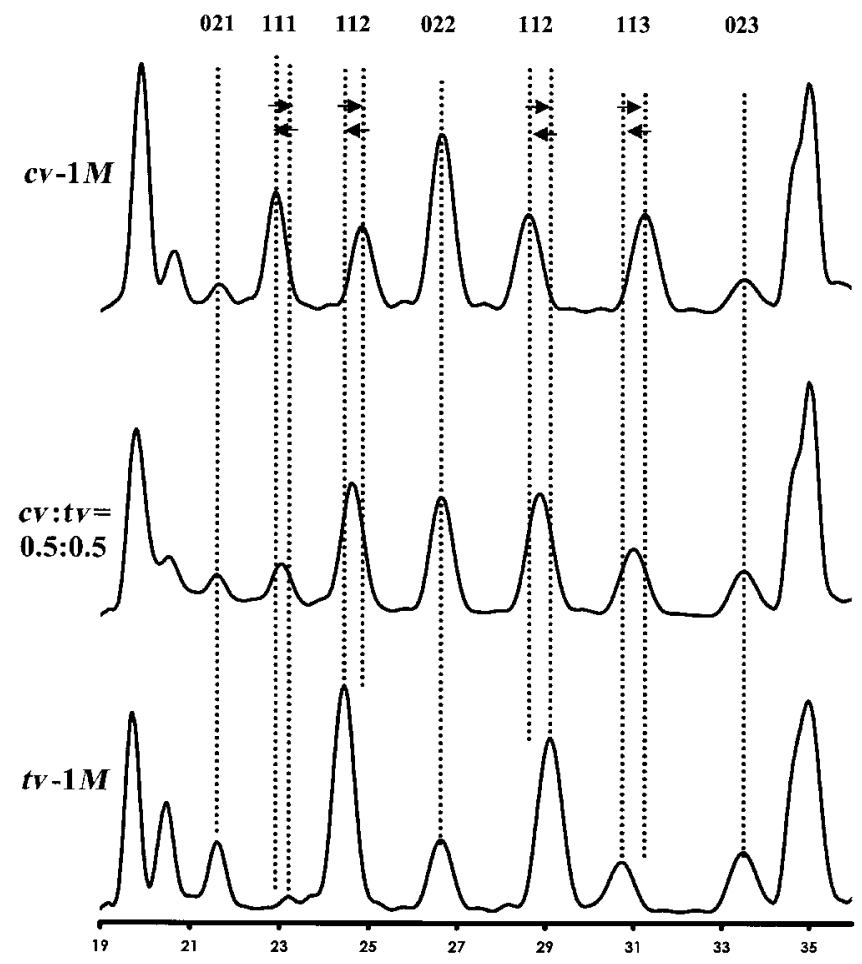

FIG. 3. The upper, middle and lower XRD patterns correspond to $c v-1 M, c v / t v-1 M$ and $t v-1 M$ structural models. For the $c v / t v-1 M$ model $11 l$ reflections are located between positions of the $11 l$ reflections corresponding to the $c v-1 M$ and $t v-1 M$ which are shown by vertical lines.

middle curve corresponds to a structure in which $t v$ and $c v$ layers are interstratified in equal proportions. One can see that $11 l$ reflections are shifted and located between the $11 l$ reflections corresponding to pure $t v$ and pure $c v$ micas whereas $02 l$ reflections have the same positions for the three patterns because they do not depend on $\beta$. In general, the positions of $11 l$ reflections depend on the content of $t v$ and $c v$ layers and will migrate within the interval restricted by the vertical lines in Fig. 3. This observation has a general meaning - interstratification of two interlayer translations shift $h \mathrm{kl}$ reflections sensitive to these translations and the positions of these reflections become irrational, i.e. they do not obey Bragg's law.

To account for the behaviour of non-basal reflections for any layer defective structures in which two translations are irregularly interstratified, Méring's rules can be generalized. According to these generalizations, the non-basal reflections are located between the neighbouring $h k l$ reflections of the periodic phases whose elementary layer units are interstratified. The positions of these reflections depend on the relative proportions of the interstratified interlayer translations. These simple rules are very useful for the identification of the nature of the interstratified components and are effectively used for determination of $t v$ and $c v$ layer contents in I-S (Drits \& McCarty, 1996; Drits et al., 1996), as well as for the determination of stacking faults in various birnessite varieties (Drits et al., 1998c; Lanson et al., 2000, 2002) and in layer double hydroxides (Drits \& Bookin, 2001).

\section{Determination of tv and cv layers in I-S having turbostratic structures}

Neither of the diffraction techniques described above can be applied if powder XRD patterns do not contain three-dimensional diffraction maxima in the diagnostic region containing $11 l$ and $02 l$ reflections. In this case the proportions of $t v$ and $c v$ layers can be determined with the help of the third method based on the analysis of losses of 
structural water during dehydroxylation(Drits et al., 1998b). This technique employs DTA in combination with evolved-water analysis. As a matter of fact, for quite a long time it remained unclear why the dehydroxylation temperature of fine dispersed and highly disordered dioctahedral smectites is $150-200^{\circ} \mathrm{C}$ higher than that of illites which have very ordered structures. Moreover, I-S often have two dehydroxylation maxima at different temperatures. On the other hand, certain so called 'abnormal' illites have the same dehydroxylation temperatures as that of typical smectite. Interpretation of the observed thermal effects was given when different structural features of $t v$ and $c v$ layers, as well as different structural mechanisms of their dehydroxylation were taken into account (Drits et al., 1995; Muller et al., 2000a,b,c). For $t v$ layers, dehydroxylation occurs in one stage, when each two adjacent hydroxyls are replaced by a residual oxygen atom, which leads to five-fold coordination for $\mathrm{Al}$. In this case dehydroxylation occurs at temperatures below $600^{\circ} \mathrm{C}$, independent of whether these layers belong to an illite or smectite.

In $c v$ structures, dehydroxylation occurs in two stages (Drits et al., 1995). At the first stage, each two adjacent hydroxyls are replaced by a residual oxygen atom, and the cations that originally occupied cis- and trans-sites become 5- and 6-coordinated, respectively. The resulting structure, however, is unstable, and any movement of the cation within the 6-coordinated octahedron should be unstable to compensate for the charge imbalance. Therefore, when additional thermal energy is applied, each cation initially occupying a transsite migrates to the nearest five-fold coordination polyhedron corresponding to the initially vacant $\mathrm{cis}$ site, and the resulting structure is the same as that in the case of dehydroxylated $t v$ layers. This complex structural rearrangment of $c v$ layers during dehydroxylation reaction increases the dehydroxylation temperature of $c v$ smectites and $c v$ illite up to $650-700^{\circ} \mathrm{C}$. It is likely that another major factor responsible for higher dehydroxylation temperature in $c v$ layers is the considerable lengthening of the $\mathrm{OH}-\mathrm{OH}$ edges in $c v$ layers in comparison with the $\mathrm{OH}-\mathrm{OH}$ edges in the $t v$ layers: the longer the distances, the greater the thermal energy required to provide the opportunity for hydrogen to jump to the nearest $\mathrm{OH}$ group to form a water molecule (Drits et al., 1995).

Comparison of the results obtained by XRD and thermal analysis showed that losses of structural water above and below $600^{\circ} \mathrm{C}$ occurred during dehydroxylation of smectites, I-S and illites are proportional to the $c v$ and $t v$ layer contents (Drits $e t$ al., 1998b, 2002a; Lindgreen et al., 2000, 2002).

\section{Some problems in the identification of the actual structure of dioctahedral micas}

Zvyagin et al. (1985) were the first to describe a monomineral Al-rich $1 M$ mica consisting of $c v$ layers. Later Reynolds \& Thomson (1993) and Drits et al. (1993) also described Al-rich $c v 1 M$ illites. They noted that the $t v-3 T$ and $c v-1 M$ polymorphs produce similar diffraction effects, i.e. in their patterns, $h k l$ reflections have similar intensities and close positions. These features explain the reason for confusion with identification of $t v-3 T$ illite. Careful analysis of the experimental data published in the literature showed that illite varieties described as $t v$-3T (Warshaw, 1959; Ey, 1984; Halter, 1988; Horton, 1983) in fact correspond to $c v-1 M$ (Drits et al., 1993). Reliable identification of $t v-3 T$ and $c v-1 M$ illites is possible if their XRD patterns contain sharp diffraction maxima. However, the broader reflections from illite and I-S (due to rotational disorder) preclude the precise location of peak positions and make it difficult to determine their actual layer stacking.

An even more complex problem is to distinguish a periodic $t v-3 T$ mica polytype from mica structures in which $t v$ and $c v$ layers are interstratified in such a way that each layer, independent of octahedral cation distribution, is rotated with respect to the preceding one by $120^{\circ}$, as in the periodic $3 T$ structure. In this case, positions of $h k l$ reflections will be the same as those in the periodic $3 T$ structure.

Figure 4 shows that XRD patterns of the periodic $3 T$ dioctahedral mica (solid line) and the interstratified structure almost coincide, when the $c v$ layer content is $20 \%$ and are still very similar when the $c v$ layer content reaches $40 \%$. Formally, the quality of these patterns is quite acceptable for the Rietveld refinement, but the refined results would be wrong if the initial model consisted only of $t v$ layers. This result is not surprising because XRD patterns of $t v 3 T$ and $c v 3 T$ have the same positions and shape of maxima and differ from each other mainly by distribution of $10 \mathrm{l}$ reflection intensities.

Diffraction effects from a $t v 2 M_{1}$ structure are more sensitive to the presence of $c v$ layers. However, the XRD patterns of a periodic $t v 2 M_{1}$ 


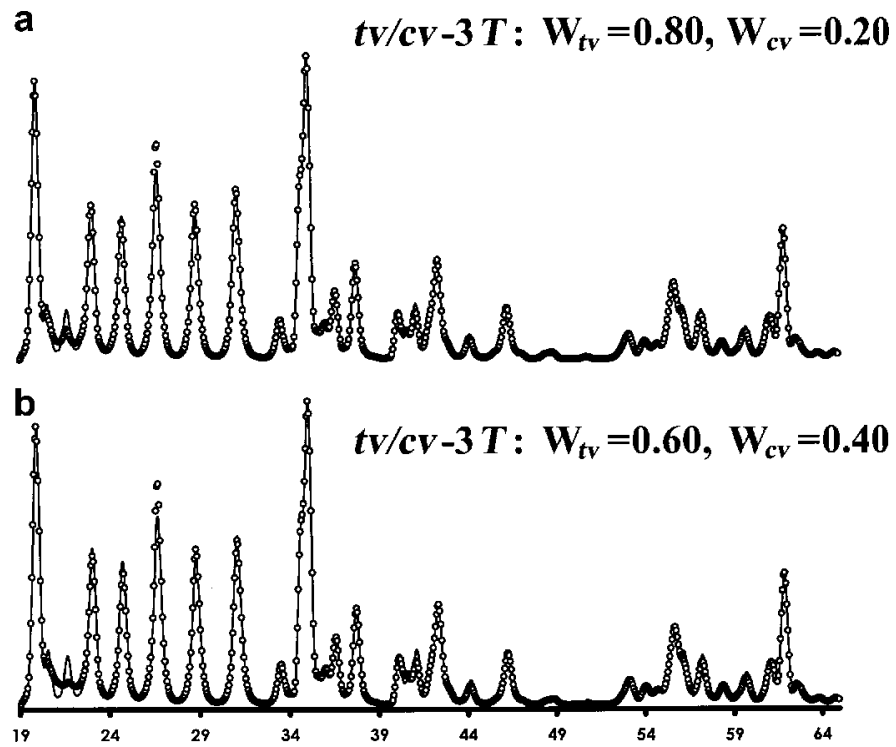

FIG. 4. Comparison of XRD patterns calculated for mixed-layer $c v / t v-3 T$ structural models containing $20 \%$ (a) and $40 \%$ (b) $c v$ layers (dotted line) and for the periodic $t v-3 T$ structure (solid line).

structure and that containing $20 \%$ of $c v$ layers are very similar (Fig. 5a).

Recently, Pavese et al. (2001) studied $3 T$ and $2 M_{1}$ powder phengites using low-temperature neutron diffraction and the Rietveld technique. They found that occupancies of trans-octahedra of these micas are not zero but roughly equal to 0.18 and 0.12 atoms per octahedron. The title of their paper contains a question: are these occupancies real or artefact?

To explain the observed results the authors postulated a stacking disorder consisting of $\pm b / 3$ slips in the octahedral sheet of the 2:1 layers occurring in $2 M_{1}$ and $3 T$ phengites. These slips move the upper plane of the apical oxygens atoms with respect to the lower plane in the octahedral sheet. In order to preserve the interlayer coordination for $\mathrm{K}$ cations, the $\pm b / 3$ shifts in the $n^{\text {th }}$ layer require the same shift for the layer located just above it. The presence of such defects is accompanied by displacements of some octahedral and tetrahedral cations as well as oxygen atoms from their standard positions to those which are unoccupied in the defect-free polytypes. The contribution of these 'shifted' atoms disturbs the reflections' intensities. Due to the ability of diffraction to average structural parameters, an XRD pattern from the $\pm b / 3$ disordered mica structure should be treated in terms of the unit cell in which occupancies can appear in positions generated by the structural disorder. In particular, the position of a filled cis-site comes to that corresponding to a vacant trans-site in the defectfree structure. Pavese et al. (2001) assumed that the scaling of the structural factors should greatly smooth the effect of the contribution of the shifted atoms to the reflections' intensities, but they did not estimate this effect quantitatively.

Analysis of the XRD patterns calculated from the $\pm b / 3$ disordered $2 M_{1}$ and $3 T$ models shows that the main contribution to the modification of the patterns results not from the partial occupancy of trans-sites in the defective layers but from the disordered displacements of the tetrahedral sheets and oxygen atoms of the octahedral sheets in these layers by $\pm b / 3$. Indeed a partial occupancy of transsites redistributes intensities of some reflections but does not change the background. In contrast, as can be seen in Fig. $5 b$ the $\pm b / 3$ layer displacements in the defective $3 T$ phengite model decrease the intensities of all $10 l$ reflections and dramatically increase the background. These features are typical of the XRD patterns of the $\pm b / 3$ disordered phyllosilicates (Drits \& Tchoubar, 1990; Drits et al., 1984). As a consequence, the background increases and the $10 \mathrm{l}$ reflection intensities decrease so dramatically that the scaling of the structural factors cannot smooth this effect. 

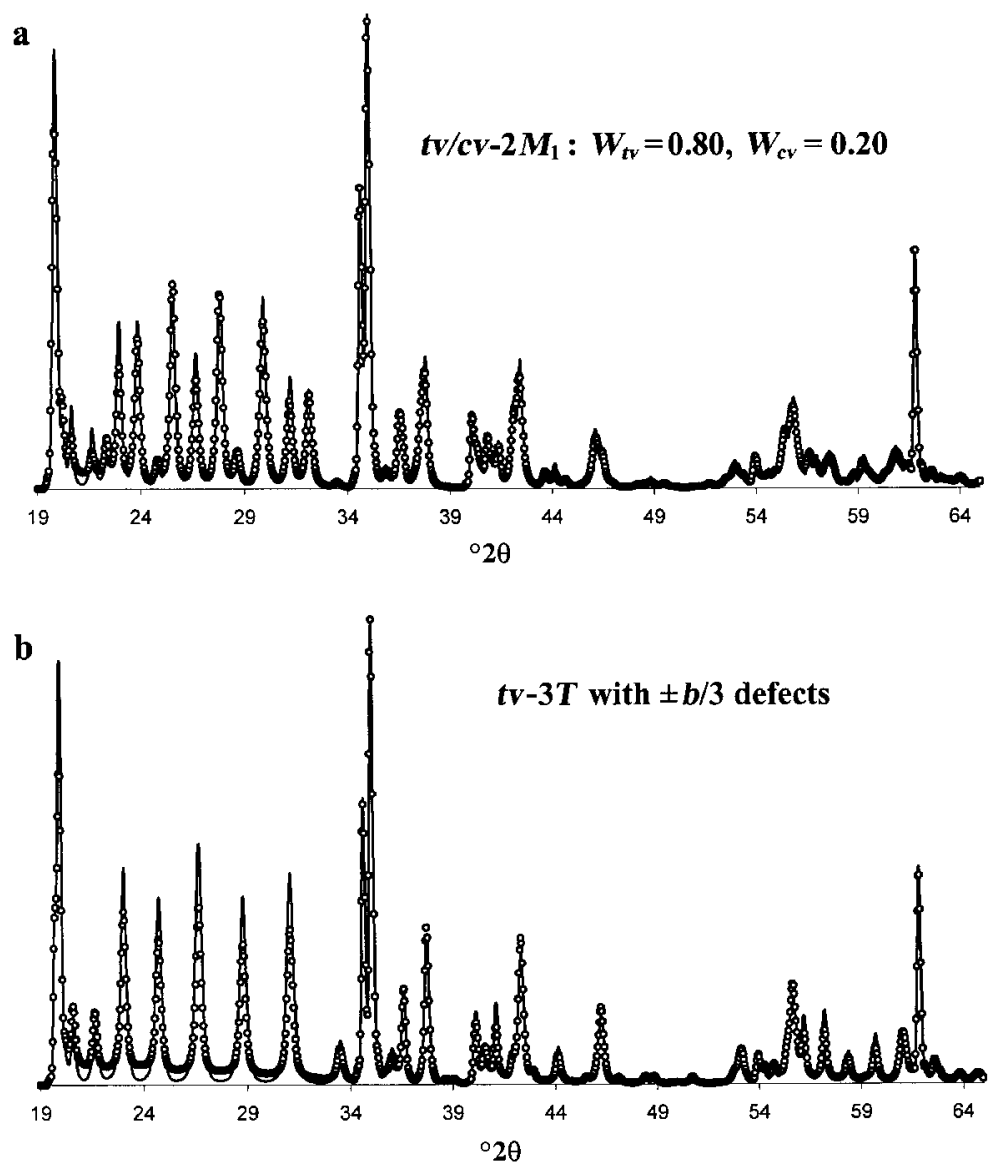

FIG. 5. Comparison of XRD patterns calculated for the periodic $t v-2 M_{1}$ (upper curve, solid line) and $t v-3 T$ (lower curve, solid line) structural models as well as for the $c v / t v-2 M_{1}$ structure containing $20 \%$ of $c v$ layers (upper curve, dotted line) and for the $\pm b / 3$ disorder $t v-3 T$ structure containing $20 \%$ of defective $\mathrm{T}^{\mathrm{u}}$ and $\mathrm{T}^{l}$ layers (lower curve, dotted line).

An alternative and crystallochemically more plausible explanation of the results obtained by Pavese et al. (2001) is associated with interstratification of $t v$ and $c v$ layers in the studied micas. Diffraction effects from $t v / c v 2 M_{1}$ and $t v / c v 3 T$ models can also be treated in terms of the averaged unit cell in which both trans- and cis-sites should be partially occupied. It means that the main modification of the XRD patterns from the $t v / c v 3 T$ structures appears as a result of the partial occupancy of transsites mimicking the presence of $c v$ layers in the actual structure. Moreover, the same reason might explain the uncertainty in the literature concerning the cation distribution over octahedral and tetrahedral sites in $3 T$ phengites determined by the Rietveld technique (Pavese, 2002). An independent means by which to solve the problem is to use thermal analysis, taking into account that $t v$ and $c v$ layers have different dehydroxylation temperatures.

\section{Simulation of two-dimensional distributions of isomorphous cations in tv and $c v$ 2:1 layers}

Spectroscopic methods are a very effective tool for determining isomorphous cation distribution, since they probe local cation environments and can detect short-range order in the cation arrangements. Information concerning the vacancy distribution over trans- and cis-sites in octahedral sheets of the 2:1 layers is one of the basic requirements for correct interpretation of experimental data obtained by spectroscopic methods. 
To make this clear, one can recall the history of the interpretation of Mössbauer spectra of $\mathrm{Fe}^{3+}$ bearing dioctahedral 2:1 layer silicates. For a long time these spectra were decomposed into two main doublets. One of them was assigned to $\mathrm{Fe}^{3+}$ in transsites whereas the other was assigned to $\mathrm{Fe}^{3+}$ in cissites (Heller-Kallai \& Rosenson, 1981; De-Grave et al., 1985). Application of diffraction methods has shown, however, that Fe-rich dioctahedral layer silicates such as glauconites, celadonites and nontronites consist only of $t v$ layers (Besson et al., 1983a; Sakharov et al., 1990; Manceau et al., 2000). Therefore, the conventional interpretation of the Mössbauer spectra had to be revised and a new approach for their interpretation was developed (Dainyak et al., 1984a,b,c, 1992; Dainyak \& Drits, 1987; Drits et al., 1997c). Its main assumption is that the observed difference in quadrupole splittings of $\mathrm{Fe}^{3+}$ cations is caused by the distortion of $\mathrm{Fe}^{3+}$ octahedra due to different local cation environments around these octahedra. However, in $c v$ smectites, $c v$ illites and in I-S containing interstratified $t v$ and $c v$ layers, $\mathrm{Fe}^{3+}$ can occupy cis- as well as transoctahedra.

Two alternatives should be considered. The first one assumes that the observed difference in the quadrupole splittings of $\mathrm{Fe}^{3+}$ depends mainly on local cation arrangements around a central $\mathrm{Fe}^{3+}$ and that the location of $\mathrm{Fe}^{3+}$ in cis- or trans-octahedra does not significantly influence the quadrupole splitting values. Similarly, frequencies of OH IR vibrations depend mainly on the nature of cations bonded to $\mathrm{OH}$ groups, and the distribution of the cations between cis- and trans-octahedra has a smaller effect on the frequencies. The alternative assumption includes a decisive or at least significant role for mutual disposition of $\mathrm{OH}$ groups for spectroscopic characteristics of dioctahedral 2:1 layer silicates. In this case, for example, the location of $\mathrm{Fe}^{3+}$ in cis- and trans-octahedra should have a stronger influence on the quadrupole splitting than the local cation environment. The results obtained by IR and Mössbauer spectroscopy for I-S samples in which either $c v$ or $t v$ layers prevail support the first alternative because the IR and Mössbauer parameters are almost independent of the content of $c v$ and $t v$ layers in the studied minerals (Drits et al., 2002a).

If these conclusions are valid, then trans- and cisvacant 2:1 layers in illite or smectite having the same cation composition and the same local cation environments around $\mathrm{Fe}$ and $\mathrm{OH}$ groups may have different octahedral cation distributions. For example, Fig. 6a shows the two-dimensional distribution of $\mathrm{Al}, \mathrm{Mg}$ and $\mathrm{Fe}^{3+}$ cations in a $t v$ octahedral sheet in which each $\mathrm{Fe}^{3+}$ is surrounded by one $\mathrm{Fe}^{3+}$ and two $\mathrm{Al}$ cations and $\mathrm{OH}$ groups are bonded to 20 $\mathrm{Al}-\mathrm{Al}, 12 \mathrm{Al}-\mathrm{Fe}^{3+}$ and $8 \mathrm{Al}-\mathrm{Mg}$ cationic pairs. As can be seen in Fig. 6a, Fe-Fe pairs are oriented along directions rotated by $\pm 60^{\circ}$ with respect to the $b$ axis. The cation distribution in a $c v$ sheet in Fig. $6 \mathrm{~b}$ has the same local cation environments around $\mathrm{Fe}^{3+}$ and $\mathrm{OH}$ groups as those in the $t v$ sheet shown in Fig. 6a. However, to provide these local cation environments $\mathrm{Fe}-\mathrm{Fe}$ pairs must be oriented along the $b$ axis.

In contrast, $t v$ and $c v$ layers having identical or similar two-dimensional cation distributions should be characterized by different spectroscopic parameters. For example, Fig. 7a shows the twodimensional cation distribution in a $t v$ octahedral sheet in which $\mathrm{Fe}$ cations are segregated into chains in such a way that there are no $\mathrm{Fe}^{3+}-\mathrm{Fe}^{3+}$ cationic pairs bonded to $\mathrm{OH}$ groups. It is clear that IR spectroscopic characteristics in the $\mathrm{OH}$-stretching and bending regions are not sensitive to such a distribution of $\mathrm{Fe}^{3+}$ cations and should be the same if the nearest positions of $\mathrm{Al}$ and $\mathrm{Fe}^{3+}$ cations bonded to $\mathrm{OH}$ groups are exchanged. In this case, each $\mathrm{Fe}^{3+}$ cation will be surrounded only by $\mathrm{Al}$ cations. However, if each local cation environment around $\mathrm{Fe}$ and its proportion are known from the Mössbauer spectrum interpretation, then, in combination with the IR data, the actual two dimensional cation distribution shown in Fig. 7a can be simulated. In contrast, the same segregation of $\mathrm{Fe}$ in $c v$ layers must be accompanied by formation of a significant amount of $\mathrm{Fe}-\mathrm{Fe}$ pairs bonded to $\mathrm{OH}$ groups whereas local cation environments around Fe remain the same as in $t v$ layers (Fig. $7 b$ ).

Thus these two models should form quite similar Mössbauer spectra but different IR spectra in the $\mathrm{OH}$-stretching and bending regions. If, for example, information about local environments around $\mathrm{OH}$ groups and $\mathrm{Fe}^{3+}$ obtained for $c v$ layers by spectroscopic methods is applied to $t v$ layers, the simulated cation distribution will be incorrect.

These examples demonstrate that in order to simulate the actual distribution of isomorphous cations in dioctahedral layer silicates of complex cation composition, at least four requirements should be met: (1) interpretation of spectroscopic data should be carried out in the light of diffraction data, i.e. average occupancy and composition of 


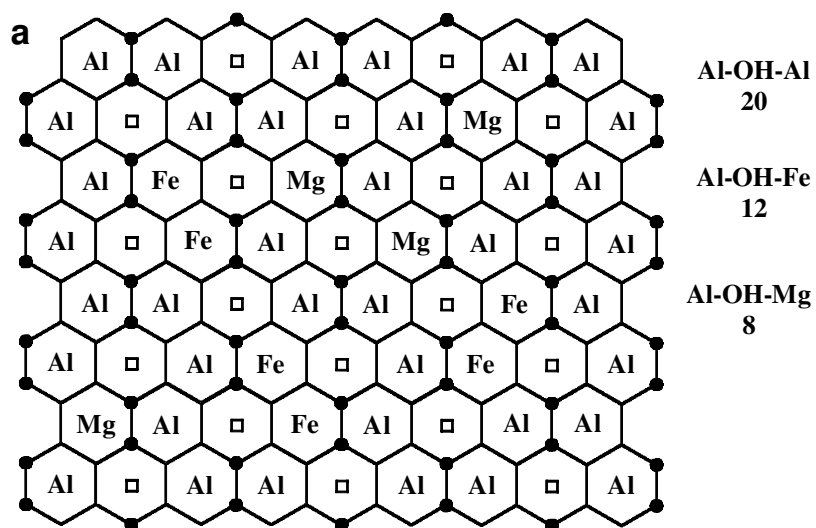

b

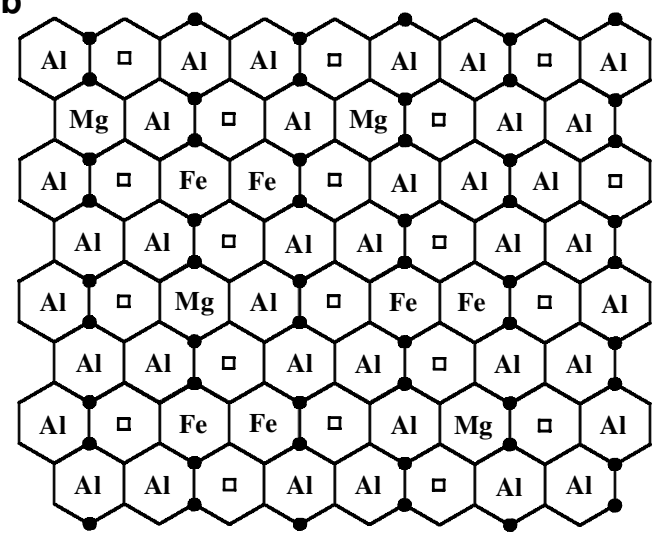

\section{Al-OH-Al}

20

Al-OH-Fe

12

Al-OH-Mg

8

FIG. 6. Two-dimensional distributions of cations in trans-vacant (a) and cis-vacant (b) octahedral sheets. On the right, different local cation environments around $\mathrm{OH}$ groups and their numbers are shown.

crystallographic sites should be determined for the sample under study; (2) at least two complementary spectroscopic methods should be applied to the same sample; (3) reliable interpretation of the experimental data obtained by each method should be provided; and (4) computer simulation of the two-dimensional cation distribution should satisfy the experimental data obtained by different methods equally well.

Simultaneous satisfaction of these requirements is a complex problem and at present, there are only a few publications devoted to simulation of octahedral cation distribution in dioctahedral layer silicates. Remarkably, most of them appeared in the last 5-10 years (Palin et al., 2001; Cuadros et al., 1999; Manceau et al., 2000; Sainz-Diaz et al., 2001a; Drits et al., 1997c; Dainyak et al., 1992;
Schroeder, 1993; Schroeder \& Pruet, 1996; Müller et al., 1997). The reason is that during this period significant progress has been achieved in the empirical and theoretical methodological developments of spectroscopic methods.

In particular, a new level in the determination of local structural environments around heavy metal cations in various layer minerals has been achieved due to development of polarized EXAFS spectroscopy effectively combined with the conventional powder EXAFS technique (Manceau et al., 1988, 1998, 1999).

${ }^{29} \mathrm{Si}$ MAS NMR has been shown to be a sensitive probe of tetrahedral $\mathrm{Si}$ and $\mathrm{Al}$ order-disorder in alumosilicate minerals and in layer silicates in particular (Herrero et al., 1987; Herrero \& Sanz, 1991; Palin et al., 2001; Vinograd, 1995). Lausen et 


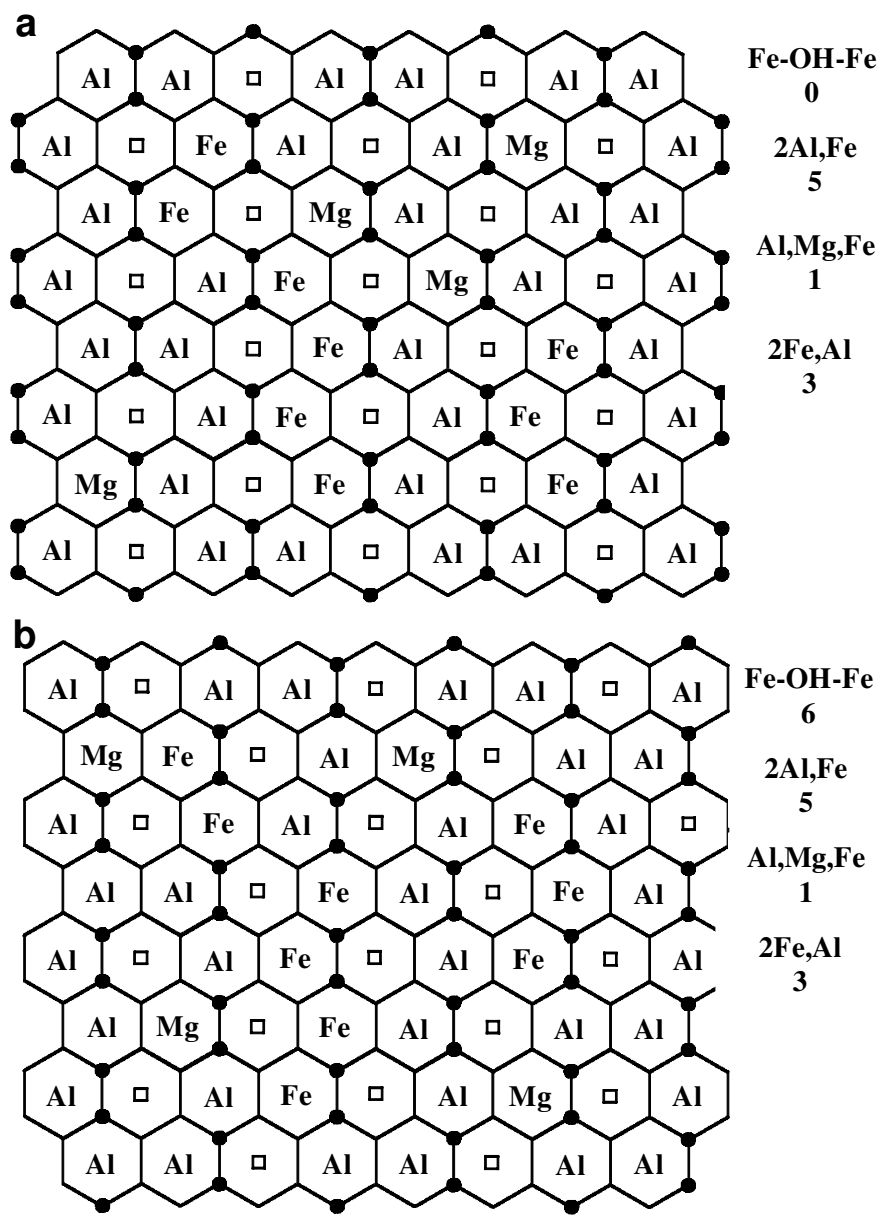

Fig. 7. Two-dimensional distributions of cations in trans-vacant (a) and cis-vacant (b) octahedral sheets. On the right, local cation environments around $\mathrm{Fe}$ octahedra and their numbers as well as numbers of $\mathrm{Fe}-\mathrm{OH}-\mathrm{Fe}$ configurations are shown.

al. (1999) suggested a procedure for iterative fitting of Si NMR spectra of I-S to determine cation compositions of tetrahedral sheets forming illite and smectite interlayers. New opportunites for MAS NMR spectroscopy are associated with the fact that for layer silicates of known cation composition, the intensity of the Al signal can be used to determine short-range order in Fe-distribution (Schroeder, 1993; Schroeder \& Pruett, 1996; Cuadros et al., 1999).

The reliable interpretation of Mössbauer spectra of $t v$ 2:1 micaceous minerals of various cation composition has been simplified by the opportunity to predict quadrupole splitting for each local cation environment around $\mathrm{Fe}^{3+}$ (Drits et al., 1997c). In IR spectroscopy, determination of the frequency for each pair of cations bonded to $\mathrm{OH}$ groups provides reliable interpretation of IR spectra of dioctahedral mica-like minerals in the $\mathrm{OH}$-stretching vibration region (Besson \& Drits, 1997a,b).

$A b$ initio quantum mechanical modelling of IR frequencies of the $\mathrm{OH}$ groups in dioctahedral 2:1 layer silicates using Hartree-Fock (HF) and Density Functional Theory (DFT) provides a new insight into the physical mechanisms that govern the $\mathrm{OH}$ vibrations observed experimentally (Kubicki et al., 1996; Sainz-Diaz et al., 2000; Martinez-Alonso et $a l ., 2002 \mathrm{a}, \mathrm{b})$. In particular, the modelled frequencies in the bending vibration region reproduce the experimental ones since their values are mainly 
determined by the nature of the neighbouring octahedral cations. In contrast, noticeable discrepancies between calculated and experimental frequencies in the stretching vibration region were explained by the influence of factors other than the nature of the neighbouring octahedral cations bonded to $\mathrm{OH}$ groups. Sainz-Diaz et al. (2000) found correlations between the atomic weights and the Milliken charges of the cations with the experimental and theoretical $\mathrm{OH}$ vibration frequencies, whereas Martinez-Alonso et al. (2002a,b) found that the mass of the octahedral cations does not affect the $\mathrm{OH}$ vibrations. It follows from their calculations that undersaturated charges of apical $\mathrm{O}$ atoms of the tetrahedral sheet can explain the observed discrepancies between the experimental and calculated $\mathrm{OH}$-stretching vibrations.

Obviously, the greater the number of methods involved, the more comprehensive the structural information obtained. Each method, however, has its own advantages and limitations and therefore provides only a partial solution to the general problem of cation order-disorder in 2:1 dioctahedral phyllosilicates. Therefore, even if unambiguous interpretation of experimental data is provided, the actual cation distribution pattern can hardly be achieved even using a combination of various diffraction and spectroscopic methods.

The solution to this problem proposed by Dainyak et al. (1992), Cuadros et al. (1999) and Sainz-Diaz et al. (2001a) was based on computer simulation of the two-dimensional distribution of isomorphous octahedral cations in dioctahedral 2:1 phyllosilicates. In fact, this approach can be considered as a 'bridge' between the data obtained by different methods as well as between short-range and long-range cation order. Application of different spectroscopic methods along with the new methodologies shows that along with random cation distribution, clustering of isomorphous cations is wide-spread.

Dainyak et al. (1992), using IR and Mössbauer techniques in combination with computer simulation, showed that glauconite B.Patom is composed of small illite-like and celadonite-like clusters. In addition, in the celadonite-like clusters there is a tendency for each trivalent cation to be surrounded by divalent cations and vice versa, providing homogeneous anion negative charge compensation. Similar regularities were found in celadonites, glauconites and Fe-illites by combining XRD, EXAFS, IR, Mössbauer and computer simulation
(Drits et al., 1997c). Müller et al. (1997) showed, using XRD, EXAFS and IR, that $\mathrm{Fe}$ and $\mathrm{Mg}$ are segregated in small clusters in the aluminous octahedral sheet of the Camp-Bertaux montmorillonite.

Cuadros et al. (1999) and Sainz-Diaz et al. (2001a) studied cation distributions in the octahedral sheets of bentonitic I-S using ${ }^{27} \mathrm{Al}$ MAS NMR, IR and inverse Monte Carlo simulation techniques. They found that $\mathrm{Fe}$ cations in the octahedral sheet have a tendency to be segregated and $\mathrm{Fe}$ segregation increases with illite proportion in the I-S. In contrast, $\mathrm{Mg}-\mathrm{Mg}$ pairs were not detected, i.e. $\mathrm{Mg}$ cations are dispersed among other cations.

Almost random distribution of $\mathrm{Fe}, \mathrm{Mg}$ and $\mathrm{Al}$ cations was found in SWa-1 nontronites by EXAFS and IR spectroscopies, although (Al, Mg)-(Al, Mg) pairs are preferentially aligned along the $\mathrm{b}$ axis and $\mathrm{Fe}-(\mathrm{Al}, \mathrm{Mg})$ pairs along the [310] and [310] directions (Manceau et al., 2000).

A theoretical study of octahedral cation distribution in dioctahedral 2:1 layer silicates using $a b$ initio calculations has been made by Sainz-Diaz et al. (2002). In particular, they found that Mg cations have a tendency to be dispersed in the octahedral sheet, in contrast to $\mathrm{Fe}^{3+}$ cations that have a tendency to segregation.

In spite of the essential progress in the study of short-range order in cation distribution, the reliability of some results remains questionable. The main reason is the existence of unsolved problems in reliable interpretation of experimental data obtained by different spectroscopic methods. For example, assignments of $\mathrm{OH}$ stretching vibrations for dioctahedral smectites are still debatable (Madejová et al., 1994; Fialips et al., 2002a,b; Zviagina et al., 2002). Similar problems exist in identification of individual $\mathrm{OH}$-bending frequencies for dioctahedral 2:1 layer silicates (Fialips et al., 2002a,b; Martinez-Alonso et al., 2002a,b). Recently Cuadros \& Altaner (1998a,b) decomposed the bending vibration regions of IR spectra for bentonitic I-S samples and found that the cation composition of the octahedral sheets calculated from the integrated intensities of the decomposed $\mathrm{OH}$ bands correlated with structural formulae based on chemical composition (Cuadros et al., 1999). It was assumed that as in the stretching vibration region (Besson \& Drits, 1997a; Slonimskaya et al., 1986), the integrated intensity of the individual $\mathrm{OH}-$ bending band is proportional to the occurrence probability of a specific cation pair. In addition, this 
domain is not affected by the presence of residual water molecules and it seemed that decomposition in this region was easier because band assignments were more straightforward (Vantelon et al., 2001). However, Fialips et al. (2002a), analysing the bending $\mathrm{OH}$-vibration region of SWa-1 nontronite, argued that the absorptivity of the different cationic pairs bonded to $\mathrm{OH}$ groups in this region could be different.

Predictions following from the theoretical calculations do not always correspond to actual cation distribution. For example, according to calculations made for the $\mathrm{Mg}_{2} \mathrm{Al}_{2}$ octahedral composition of $\mathrm{Ca}$ and K-bearing mica-like structures, the most stable distribution corresponds to a model where $\mathrm{Mg}$ cations are completely dispersed among $\mathrm{Al}$ cations and $\mathrm{Mg}-\mathrm{Mg}$ cationic pairs are absent. However, according to the IR experimental data, leucophyllites having idealized composition $\mathrm{KSi}_{4} \mathrm{Al}_{1} \mathrm{Mg}_{1} \mathrm{O}_{10}(\mathrm{OH})_{2}$, contain a significant amount of $\mathrm{Mg}-\mathrm{Mg}$ pairs bonded to $\mathrm{OH}$ groups (Besson \& Drits, 1997a). Indirect but strong theoretical and experimental evidence for the existence of $\mathrm{Mg}-\mathrm{OH}-\mathrm{Mg}$ cation arrangements in cv montmorillonite from Camp-Bertaux was obtained from Méring \& Glaeser (1954). Further theoretical and empirical investigations are required to provide unambiguous interpretation for spectroscopic data and thus to provide unambiguous cation distribution determinations.

\section{QUANTITATIVE SPECIATION OF HEAVY METALS IN SOILS, SEDIMENTS AND SOLID WASTE}

Owing to their unique redox and sorption properties, clay minerals, Fe (oxyhydr)oxides and $\mathrm{Mn}$ oxides play a pivotal role in the transport and fate of heavy metals and other pollutants contaminating the surface of the earth. Therefore, a comprehensive structural and crystal chemical study of these minerals is required in order to understand the atomic-scale bonding mechanisms of metals incorporated in a mineral structure, oxidation state and local structural environments of these metals, and thus provide a solid scientific base for modelling the extent and kinetics of chemical reactions in soils, sediments and solid waste. Because the toxicity of metals depends strongly on their oxidation states and their bonding with the mineral host, determination of various forms of toxic metals in natural systems is a fundamental task of the environmental science. Soils and sediments, however, are multicomponent and open systems in which different heavy metals can be distributed heterogeneously within the complex heterogeneous assemblage of minerals. Therefore, for a long time, structural and chemical forms of trace elements in heterogeneous natural matrices were questionable. A new level in the quantitative speciation of heavy metals has recently been achieved due to the development of new methodologies based on advanced synchrotron X-ray techniques. In a set of publications, Manceau et al. $(2000,2002 \mathrm{a}, 2003)$ have shown that combination of scanning X-ray microfluorescence ( $\mu$ SXRF), microdiffraction ( $\mu$ SXRD) and microextended $\mathrm{X}$-ray absorption fine structure ( $\mu$ EXAFS) spectroscopy provides a new insight into uptake mechanisms of heavy metals by soil constituents determining structural forms of heavy metals and their contents in each particular soil mineral. The first two techniques can identify the host phase by mapping the distribution of elements and solid species, respectively, whereas $\mu$ EXAFS can determine local structure of metals in a particular mineral and the molecular-scale bonding mechanisms of transition elements by the host phase. The unique opportunities of these techniques have been illustrated by Manceau et al. (2000, 2002a, 2003), Strawn et al. (2002) and Isaura et al. (2002) who studied quantitative speciation of $\mathrm{Zn}$ and $\mathrm{Ni}$ in soil ferromanganese nodules, smelter-contaminated soils and $\mathrm{Zn}$-contaminated sediments. In particular, it was shown that: in smectites the local structure around $\mathrm{Zn}$ is trioctahedral; in birnessite $\mathrm{Zn}$ cations are located in the interlayers above or below the layer vacant octahedra and can have four- and/or six-fold coordination, whereas in $\mathrm{Zn}$-bearing $\mathrm{Fe}$ hydroxides, $\mathrm{Zn}$ cations have a ferrihydrite local structure. The study of Ni-bearing soil Fe-Mn nodules showed that the substitution of $\mathrm{Mn}^{3+}$ for $\mathrm{Ni}$ in the Mn layers of lithiophorite is characteristic for such micronodules. Manceau et al. (2002b) presented the state of the art in the environmental geochemistry of heavy metals.

\section{ACKNOWLEDGMENTS}

I am grateful to S. Hillier and two anonymous referees for their valuable comments and corrections to the English and to B.A. Sakharov and B.B. Zviagina for their kind help in the preparation of the manuscript. This work was supported by the Russian Science Foundation. 


\section{REFERENCES}

Altaner S.P. \& Ylagan R.F. (1997) Comparison of structural models of mixed-layer illite-smectite and reaction mechanisms of smectite illitization. Clays and Clay Minerals, 45, 517-533.

Arkai P., Merriman R.J., Roberts B., Peacor D.R. \& Toth M. (1996) Crystallinity, crystallite size and lattice strain of illite-muscovite and chlorite: comparison of XRD and TEM data for diagenetic to epizonal pelites. European Journal of Mineralogy, 8 , $1119-1138$.

Bailey S.W. (1984) Crystal chemistry of the true mica. Pp. 13-66 in: Micas (S.W. Bailey, editor). Reviews in Mineralogy 13. Mineralogical Society of America, Washington, D.C.

Bailey S.W., Banfield J.F., Barker W.W. \& Katchen G. (1995) Dozyite, a 1:1 regular interstratification of serpentine and chlorite. American Mineralogist, 80, $65-77$.

Banfield J.F. \& Murakami T. (1998) Atomic-resolution transmission microscope evidence for the mechanism by which chlorite weathers to 1:1 semi-regular chlorite-vermiculite. American Mineralogist, 83, $348-357$.

Beaufort D., Baronnet A., Lanson B. \& Meunier A. (1997) Corrensite: A single phase or a mixed-layer phyllosilicate in the saponite-to-chlorite conversion series? A case study of Sancerre-Cony deep drill hole. American Mineralogist, 82, 109-124.

Besson G. \& Drits V.A. (1997a) Refined relationships between chemical composition of dioctahedral finedispersed mica minerals and their infrared spectra in the $\mathrm{OH}$-stretching region. Part 1. Identification of the stretching bands. Clays and Clay Minerals, 45, $158-169$.

Besson G. \& Drits V.A. (1997b) Refined relationships between chemical composition of dioctahedral finedispersed mica minerals and their infrared spectra in the $\mathrm{OH}$-stretching region. Part 2. The main factors affecting $\mathrm{OH}$-vibrations and quantitative analysis. Clays and Clay Minerals, 45, 170-183.

Besson G., Bookin A.S., Dainyak L.G., Rautureau M., Tsipursky S.I., Tchoubar C. \& Drits V.A. (1983a) Use of diffraction and Mössbauer methods for the structural and crsytallochemical characterization of nontronites. Journal of Applied Crystallography, 16, $374-383$.

Besson G., Cleaser R. \& Tchoubar C. (1983b) Le cesium revelateur de structure des smectites. Clay Minerals, 18, $11-19$.

Bish D.L. \& Chipera S.J. (1998) Variation of kaolinite defect structure with particle size. Abstracts, Annual Meeting of the Clay Minerals Society, Cleveland, USA.

Bookin A.S., Drits V.A., Plançon A. \& Tchoubar C. (1989) Stacking faults in kaolin minerals in the light of real structural features. Clays and Clay Minerals, 37, 297-307.

Brindley G.W. \& Méring J. (1951) X-ray diffraction by disordered layer structure. Acta Crystallographica, 4, $441-447$.

Chukhrov F.V., Gorshkov A.I., Vitovskaya I.V., Drits V.A. \& Sivtsov A.V. (1982) On the nature of Co-Ni asbolane. Pp. 230-239 in: Ore Genesis - the State of the Art (G.G. Amstutz, A.F. Coresy, G. Franzel \& R.A. Zimmermann, editors). Springer-Verlag, Berlin.

Chukhrov F.V., Gorshkov A.I. \& Drits V.A. (1989) Hypergenic Manganese Oxides. Nauka, Moscow, $298 \mathrm{pp}$.

Cuadros J. (2002) Structural insights from the study of Cs-exchanged smectites submitted to wetting-anddrying cycles. Clay Minerals, 37, 473-486.

Cuadros J. \& Altaner S.P. (1998a) Characterization of mixed-layer illite-smectite from bentonites using microscopic, chemical and X-ray methods: constrains on the smectite-to-illite transformation mechanism. American Mineralogist, 83, $762-774$.

Cuadros J. \& Altaner S.P. (1998b) Compositional and structural features of the octahedral sheet in mixedlayer illite-smectite from bentonites. European Journal of Mineralogy, 10, 111-124.

Cuadros J., Sainz-Diaz C.I., Ramirez R. \& HernandezLaguna A. (1999) Analysis of Fe segregation in the octahedral sheet of bentonitic illite-smectite by means of FTIR, ${ }^{27} \mathrm{Al}$ MAS NMR and reverse Monte Carlo simulations. American Journal of Science, 299, 293-308.

Dainyak L.G. \& Drits V.A. (1987) Interpretation of Mössbauer spectra of nontronite, celadonite, and glauconite. Clays and Clay Minerals, 35, 363-372.

Dainyak L.G., Dainyak B.A., Bookin A.S. \& Drits V.A. (1984a) Interpretation of Mössbauer spectra of dioctahedral $\mathrm{Fe}^{3+}$-containing 2:1 layer silicates. I. Computation of electric field gradients on the basis of structural modeling. Kristallografia, 29, 94-100 (in Russian).

Dainyak L.G., Bookin A.S. \& Drits V.A. (1984b) Interpretation of the Mössbauer spectra of dioctahedral $\mathrm{Fe}^{3+}$-containing 2:1 layer silicates. II. Nontronite. Kristallografia, 29, 304-311 (in Russian).

Dainyak L.G., Bookin A.S. \& Drits V.A. (1984c) Interpretation of Mössbauer spectra of dioctahedral $\mathrm{Fe}^{3+}$-containing 2:1 layer silicates. III. Celadonite. Kristallografia, 29, 312-321 (in Russian).

Dainyak L.G., Drits V.A. \& Heifits L.M. (1992) Computer simulation of cation distribution in dioctahedral 2:1 layer silicates using IR-data: Application to Mössbauer spectroscopy of a glauconite sample. Clays and Clay Minerals, 40, 470 -479.

De Grave E., Vandenburwaene J. \& Elewaut E. (1985) An ${ }^{57} \mathrm{Fe}$ Mössbauer effect study on glauconites from 
different locations in Belgium and northern France. Clay Minerals, 20, 176-179.

Drits V.A. (1985) Some aspects of the study of the real structures of clay minerals. Proceedings of the 5th Meeting of the European Clay Groups, Prague 1983 (J. Konta, editor) pp. 33-42.

Drits V.A. (1987a) Electron Diffraction and High Resolution Electron Microscopy of Mineral Structures. Springer-Verlag, Berlin, 304 pp.

Drits V.A. (1987b) Mixed layer minerals: diffraction methods and structural features. Proceedings of the International Clay Conference, Denver, July 1985. (L.G. Schutz, H. van Olphen \& F.A. Mumpton, editors). The Clay Minerals Society, Bloomington, Indiana, pp. $33-45$.

Drits V.A. (1997) Mixed-layer minerals. Pp. 153-190 in: Modular Aspects of Minerals (S. Merlino, editor). EMU Notes in Mineralogy 1. Eötvös University Press, Budapest.

Drits V.A. \& Bookin A.S. (2001) Crystal structure and X-ray identification of Layered Double Hydroxides. Pp. 20-75 in: Layered Double Hydroxide: Present and Future (V. Rives editor). Novo Science Publishers, New York.

Drits V.A. \& McCarty D. (1996) A simple technique for a semi-quantitative determination of the trans-vacant and cis-vacant 2:1 layer contents in illites and illitesmectites. American Mineralogist, 81, 852-863.

Drits V.A. \& Plançon A. (1994) Expert system for structural characterization of phyllosilicates: II. Application to mixed-layer minerals. Clay Minerals, 29, 39-45.

Drits V.A. \& Sakharov B.A. (1976) X-ray Structural Analysis of Mixed-Layer Minerals. Nauka, Moscow, 256 pp. (in Russian).

Drits V.A. \& Tchoubar C. (1990) X-ray Diffraction of Disordered Lamellar Structures. Theory and Application to Microdivided Silicates and Carbons. Springer Verlag, Berlin, 242 pp.

Drits V.A., Plançon A., Sakharov B.A., Besson G., Tsipursky S.I. \& Tchoubar C. (1984) Diffraction effects calculated for structural models of $\mathrm{K}$ saturated montmorillonite containing different types of defects. Clay Minerals, 19, 541-562.

Drits V.A., Weber F., Salyn A. \& Tsipursky S. (1993) $\mathrm{X}$-ray identification of $1 \mathrm{M}$ illite varieties. Clays and Clay Minerals, 28, $185-207$.

Drits V.A., Varaxina T.V., Sakharov B.A. \& Plançon A. (1994) A simple technique for identification of onedimensional powder X-ray diffraction patterns for mixed-layer illite-smectites and other interstratified minerals. Clays and Clay Minerals, 42, 382-390.

Drits V.A., Besson G. \& Muller F. (1995) Structural mechanism of dehydroxylation of cis-vacant 2:1 layer silicates. Clays and Clay Minerals, 43, $718-731$.

Drits V.A., Salyn A.L. \& Šuchá V. (1996) Dynamic and mechanism in the structural transformation of illitesmectites from Dolna Ves hydrothermal deposits. Clays and Clay Minerals, 44, 181-190.

Drits V.A., Sakharov B.A., Lindgreen H. \& Salyn A. (1997a) Sequential structural transformation of illitesmectite-vermiculite during diagenesis of Upper Jurassic shales from North Sea and Denmark. Clay Minerals, 32, 351-372.

Drits V.A., Lindgreen H. \& Salyn A. (1997b) Determination by X-ray diffraction of content and distribution of fixed ammonium in illite/smectite. Application to North Sea illite-smectites. American Mineralogist, 82, 79-87.

Drits V.A., Dainyak L.G., Muller F., Besson G. \& Manceau A. (1997c) Isomorphous cation distribution in celadonites, glauconites and Fe-illites determined by Infrared, Mössbauer and EXAFS spectroscopy. Clay Minerals, 32, 153-180.

Drits V.A., Środoń J. \& Eberl D.D. (1997d) XRD measurement of mean illite crystallite thickness: Reappraisal of the Kübler index and the Scherrer equation. Clays and Clay Minerals, 45, 461-475.

Drits V.A., Eberl D.D. \& Środoń J. (1998a) XRD measurement of mean thickness, thickness distribution and strain for illite and illite-smectite crystallites by the Bertaut-Warren-Averbach technique. Clays and Clay Minerals, 46, 38-50.

Drits V.A., Lindgreen H., Salyn A.L., Ylagan R. \& McCarty D.K. (1998b) Semiquantitative determination of trans-vacant and cis-vacant 2:1 layers in illites and illite-smectites by thermal analysis and X-ray diffraction. American Mineralogist, 83, $31-73$.

Drits V.A., Lanson B., Gorshkov A.I. \& Manceau A. (1998c) Sub- and super-structure of four-layer Caexchanged birnessite. American Mineralogist, 83, 97-118.

Drits V.A., Ivanovskaya T.A., Sakharov B.A., Gor'kova N.V., Karpova G.V. \& Pokrovskaya E.V. (2001) Pseudomorphous substitution of globular glauconite by mixed-layer chlorite-berthierine. Lithology and Mineral Resources, 4, 390-407 (in Russian).

Drits V.A., Sakharov B.A., Dainyak L.G., Salyn A.L. \& Lindgreen H. (2002a) Structural and chemical heterogeneity of illite-smectites from Upper Jurassic mudstones of East Greenland related to volcanic and weathered parent rocks. American Mineralogist, 87, 1590 - 1607.

Drits V.A., Lindgreen H., Sakharov B.A., Jakobsen H.J., Salyn A.L. \& Dainyak L.G. (2002b) Tobelitization of smectite during oil generation in oil-source shales. Application to North Sea illite-tobelite-smectitevermiculite. Clays and Clay Minerals, 50, 82-98.

Dudek T., Środoń J., Eberl D.D., Elsass F. \& Uhlik P. (2002) Thickness distribution of illite crystals in shales. I: X-ray diffraction vs High-Resolution Transmission Electron Microscopy measurements. 
Clays and Clay Minerals, 50, $562-577$.

Eberl D.D., Drits V.A., Środoń J. \& Nuesch R. (1996) MudMaster: A program for calculating crystalline size distribution and strain from the shape of X-ray diffraction peaks. N.S. Geological Survey, Open-File Report, 96-171.

Eberl D.D., Drits V.A. \& Środoń J. (1998a) Deducing growth mechanisms for minerals from the shapes of crystal size distributions. American Journal of Science, 298, 499-533.

Eberl D.D., Nuesch R., Šuchá V. \& Tsipursky S. (1998b) Measurment of fundamental illite particle thicknesses by X-ray diffraction using PVP-10 intercalation. Clays and Clay Minerals, 46, 89-97.

Eberl D.D., Kile D.E. \& Drits V.A. (2002) On geological interpretations of crystal size distributions: Constant vs. proportionate growth. American Mineralogist, 87, 1235 - 1241.

Elsass F., Beaumont A., Pernes M., Jaunet A.-M. \& Tessier D. (1998) Changes in layer organization of $\mathrm{Na}$ and $\mathrm{Ca}$-exchanged smectite materials during solvent exchanges for embedment in resin. The Canadian Mineralogist, 36, 1475 -1483.

Ey F. (1984) Un exemple de gisement d'uranium sous discordance: les mineralisations proterozoiques de Cluff Lake, Saskatchewan, Canada. Thèse doctoral, Université Louis Pasteur, Strasbourg 1, France.

Fialips C.-I., Huo D., Yan L., Wu J. \& Stucki J.W. (2002a) Infrared study of reduced and reducedreoxidized ferrugious smectite. American Mineralogist, 87, 455-469.

Fialips C.-I., Huo D., Yan L., Wu J. \& Stucki J.W. (2002b) Effect of Fe oxidation state on the IR spectra of Garfield nontronite. American Mineralogist, 87, $630-641$.

Guinier A. (1964) Theorie et technique de la radiocrystallographie. Pp. 490-636 in: Diffraction par les Reseaux Crystallins Imparfaits. Dunod, Paris.

Guthrie G.D. \& Veblen D.R. (1989) High-resolution transmission electron microscopy of mixed-layer illite-smectite: computer simulations. Clays and Clay Minerals, 37, 1-11.

Halter G. (1988) Zonalite des alterations dans l'environement des gisements d'uranium associéa à la discordance du Proterozoique moyen (Saskatchewan, Canada). Thèse doctoral, Université Louis Pasteur, Strasbourg 1, France.

Heller-Kallai L. \& Rozenson I. (1981) The use of Mössbauer spectroscopy of iron in clay mineralogy. Physics and Chemistry of Minerals, 7, 223-238.

Herrero C.P. \& Sanz J. (1991) Short-range order of the $\mathrm{Si}$, Al distribution in layer silicates. Journal of Physical Chemistry Solids, 52, 1129-1135.

Herrero C.P., Gregorkeiwitz M., Sanz J. \& Serratosa J.M. (1987) ${ }^{29}$ Si MAS NMR spectroscopy of micatype silicates: observed and predicted distribution of tetrahedral Al-Si. Physics and Chemistry of
Minerals, 15, 84-90.

Horton D. (1983) Argillitic alteration associated with the amethyst vein system, Creede Mining District, Colorado. $\mathrm{PhD}$ dissertation, University of Illinois, Urbana-Champaigne, Illinois, USA.

Ivanovskaya T.A., Sakharov B.A., Gor'kova N.V., Karpova G.V., Pokrovskaya E.V. \& Drits V.A. (1999) Berthierine in catagenetically altered vendian-cambrian deposits of Podolia, Dniester region. Lithology and Mineral Resources, 2, 198-212 (in Russian).

James R.W. (1965) The Optical Principles of the Diffraction of X-rays. Cornell University Press, USA $664 \mathrm{pp}$.

Kakinoki J. \& Komura Y. (1952) Intensity of X-ray diffraction by one dimensionally disordered crystal. I. General derivation in the case of the 'Reichweite' $\mathrm{S}=0$ and 1. Journal of the Physics Society of Japan, 7, $30-35$.

Kakinoki J. \& Komura Y. (1954) Intensity of X-ray diffraction by one dimensionally disordered crystal. II. General derivation in the case of the correlation range $\mathrm{S}>2$. Journal of the Physics Society of Japan, 9, $169-176$.

Kogure T. \& Banfield J.F. (1998) Direct identification of the six polytypes characterized by semi-random stacking. American Mineralogist, 83, 925-930.

Kogure T. \& Banfield J.F. (2000) New insights into the mechanism for chloritization of biotite using polytype analysis. American Mineralogist, $\mathbf{8 5}$, $1202-1208$.

Kogure T. \& Nespolo M. (1999a) A TEM study of longperiod mica polytypes: determination of the stacking sequence of oxybiotite by means of atomic-resolution images and Periodic Intensity Distribution. Acta Crystallographica, B55, 507-516.

Kogure T. \& Nespolo M. (1999b) First occurrence of a stacking sequence including $\left( \pm 60^{\circ}, 180^{\circ}\right)$ rotations in Mg-rich annite. Clays and Clay Minerals, 47, $784-792$.

Kogure T. \& Nespolo M. (2001) Atomic structures of planar defects in oxybiotite. American Mineralogist, 86, $336-340$.

Kogure T., Hybler J. \& Durovič S. (2001) A HRTEM study of cronstedtite: Determination of polytypes and layer polarity in trioctahedral 1:1 phyllosilicates. Clays and Clay Minerals, 49, 310-317.

Kogure T., Hybler J. \& Yoshida H. (2002) Coexistence of two polytypic groups in cronstedtite from Lostwithiel, England. Clays and Clay Minerals, 50, $504-513$.

Kubicki J.D., Blake G.A. \& Apitz S.E. (1996) Ab inito calculations on alumosilicate $Q^{3}$ species: Implications for atomic structures of mineral surfaces and dissolution mechanisms of feldspars. American Mineralogist, 81, 789-799.

Lanson B., Beaufort D., Berger G., Baradat J. \& 
Lacharpaque J.-C. (1996) Late-stage diagenesis of clay minerals in porous rocks: Lower Permian Rotliegendes reservoir off-shore of the Netherlands. Journal of Sedimentary Research, 66, 501-518.

Lanson B., Drits V.A., Silvester E. \& Manceau A. (2000) Structure of H-exchanged hexagonal birnessite and its mechanism of formation from Na-rich monoclinic buserite at low $\mathrm{pH}$. American Mineralogist, 85, 826-838.

Lanson B., Drits V.A., Gaillot A-C., Silvester E., Plançon A. \& Manceau A. (2002) Structure of heavy metal sorbed birnessite: Part I. Results from X-ray diffraction. American Mineralogist, 87, 1631 - 1645.

Lausen S.K., Lindgreen H. \& Jakobsen H.J. (1999) Solid-state ${ }^{29} \mathrm{Si}$ MAS NMR studies of illite and illitesmectite from shale. American Mineralogist, 84, $1433-1438$.

Lear P.R. \& Stucki J.W. (1990) Magnetic properties and site occupancy of iron in nontronites. Clay Minerals, 25, 3-14.

Lindgreen H. \& Surlyk F. (2000) Upper Permian-Lower Cretaceous clay mineralogy of East Greenland: provenance, palaeoclimate and volcanicity. Clay Minerals, 35, $791-806$.

Lindgreen H., Drits V.A., Sakharov B.A., Salyn A.L., Wrang P. \& Dainyak L.G. (2000) Illite-smectite structural changes during metamorphism in black Cambrian Alum shales from the Baltic area. American Mineralogist, 85, 1223 - 1238 .

Lindgreen H., Drits V.A., Sakharov B.A., Jakobsen H., Salyn A.L., Dainyak L.G. \& Kroyer H. (2002) The structure and diagenetic transformation of illitesmectite and chlorite-smectite from North Sea Cretaceous-Tertiary chalk. American Mineralogist, 87, 429-450.

Ma C. \& Eggleton R.A. (1999) Surface layer types of kaolinite: a High-Resolution Transmission Electron Microscope study. Clays and Clay Minerals, 47, $181-191$.

Makovicky E. \& Hyde B.G. (1992) Incommensurate two-layer structures with complex crystal chemistry. Pp. 1-100 in: Incommensurate Misfit Sandwiched Layered Compounds. Materials Science Forum. Transactions Technical Publications, Zürich.

Madejová J., Komadel P. \& Čičel B. (1994) Infrared study of octahedral populations in smectites. Clay Minerals, 29, 319-326.

Manceau A., Bounin D., Kaiser P. \& Fretigny C. (1988) Polarized EXAFS of biotite and chlorite. Physics and Chemistry of Minerals, 16, 180-185.

Manceau A., Gorshkov A.I. \& Drits V.A. (1992) Structural chemistry of $\mathrm{Mn}, \mathrm{Fe}, \mathrm{Co}$ and $\mathrm{Ni}$ in manganese hydrous oxides: Part II. Information from EXAFS spectroscopy and electron and X-ray diffraction. American Mineralogist, 77, $1144-1157$.

Manceau A., Chateigner D. \& Gates W.P. (1998) Polarized EXAFS, distance-valence least-square modeling and quantitative texture analysis approaches to the structural refinement of Garfield nontronite. Physics and Chemistry of Minerals, 25, $347-365$.

Manceau A., Schlegel M., Chateigner D., Lanson B., Bartoli C. \& Gates W.P. (1999) Application of Polarized EXAFS to Fine-Grained Layered Minerals. Pp. 69-114 in: Synchrotron X-ray Methods in Clay Science (D. Schulze, P. Bertsch and J. Stucki, editors). CMS Workshop lecture notes, 9. Clay Minerals Society, Aurora, Colorado, USA.

Manceau A., Lanson B., Drits V.A., Chateigner D., Gates W.P., Wu J., Huo D. \& Stucki J.W. (2000a) Oxidation-reduction mechanism of iron in dioctahedral smectites. I. Crystal chemistry of oxidized reference nontronites. American Mineralogist, 85, $133-152$.

Manceau A., Lanson B., Schlegel M.L., Hargé J.C., Musso M., Eybert-Berard L., Hazemann J.L. \& Chateigner D. (2000b) Quantitative Zn speciation in smelter-contaminated soils by EXAFS spectroscopy. American Journal of Science, 300, 289-343.

Manceau A., Tamura N., Marcus M.A., MacDowell A.A., Celestre R.S., Sublett R.E., Sposito G. \& Padmore H.A. (2002a) Deciphering Ni sequestration in soil ferromanganese nodules by combining X-ray fluorescense, absorption and diffraction at micrometer scale of resolution. American Mineralogist, 87, $1494-1499$.

Manceau A., Marcus M.A. \& Tamura N. (2002b) Quantitative speciation of heavy metals in soils and sediments by synchrotron X-ray techniques. Pp. $341-428$ in: Application of Synchrotron Radiation in Low-Temperature Geochemistry and Environmental Science (P. Tender, M. Rivers, N.C. Sturchio and S. Sutton, editors). Reviews in Mineralogy and Geochemistry, 49. Mineralogical Society of America, Washington, D.C.

Manceau A., Tamura N., Celestre R.S., MacDowell A.A., Geoffrey N., Sposito G. \& Padmore H.A. (2003) Molecular- scale speciation of $\mathrm{Zn}$ and $\mathrm{Ni}$ in soil ferromanganese nodules from loess soils of the Mississippi basin. Environmental Science and Technology, 37, 75-80.

Martinez-Alonso S., Rustad J.R. \& Goetz A.F.H. (2002a) Ab initio quantum mechanical modeling of infrared vibrational frequencies of the $\mathrm{OH}$ group in dioctahedral phyllosilicates. Part I: Methods, results and comparison to experimental data. American Mineralogist, 87, 1215 - 1223.

Martinez-Alonso S., Rustad J.R. \& Goetz A.F.H. (2002b) Ab initio quantum mechanical modeling of infrared vibrational frequencies of the $\mathrm{OH}$ group in dioctahedral phyllosilicates. Part II: Main physical factors governing the $\mathrm{OH}$ vibrations. American Mineralogist, 87, $1224-1234$.

McCarty D.K. \& Reynolds R.C. (1995) Rotationally 
disordered illite-smectite in Paleozoic K-bentonites. Clays and Clay Minerals, 43, 271-284.

McCarty D.K. \& Reynolds R.C. (2001) Three-dimensional crystal structures of illite-smectite minerals in Paleozoic K-bentonites from the Appalachian basin. Clays and Clay Minerals, 49, 24-35.

Méring J. (1949) L'interference des rayons X dans les systemes a stratification desordonnee. Acta Crystallographica, 2, 371-377.

Méring J. \& Glaeser R. (1954) Sur la role de la valence cations exchangeable dans la montmorillonite. Bulletin de la Société francaise de la Minéralogie et Cristallographie, 77, 519-530.

Merriman R.J., Roberts B. \& Peacor D.K. (1990) A transmission electron microscopy study of white mica crystallite size distribution in a mudstone to slate transitional sequence, North Wales, UK. Contributions to Mineralogy and Petrology, 106, $27-40$.

Muller F., Besson G., Manceau A. \& Drits V.A. (1997) Distribution of isomorphous cations within octahedral sheets in montmorillonite from Camp-Bertaux. Physics and Chemistry of Minerals, 24, 159-166.

Muller F., Drits V.A., Plançon A. \& Besson G. (2000a) Dehydroxylation of $\mathrm{Fe}^{3+}$, Mg-rich dioctahedral micas: (I) structural transformation. Clay Minerals, 35, $491-504$.

Muller F., Drits V.A., Tsipursky S.I. \& Plançon A., (2000b) Dehydroxylation of $\mathrm{Fe}^{3+}$, Mg-rich dioctahedral micas: (II) cation migration. Clay Minerals, 35, $505-514$.

Muller F., Drits V.A., Plançon A. \& Robert J-P. (2000c) Structural transformation of 2:1 dioctahedral layer silicates during dehydroxylation-rehydroxylation reactions. Clays and Clay Minerals, 48, 5, 572-585.

Murakami T., Sato T. \& Inoue A. (1999) HRTEM evidence for the process and mechanism of saponiteto-chlorite conversion through corrensite. American Mineralogist, 84, 1080 - 1087.

Nadeau P.H., Tait J.M., McHardy W.J. \& Wilson M.J. (1984) Interstratification XRD characteristics of physical mixtures of elementary clay particles. Clay Minerals, 19, 67-76.

Organova N.I. (1989) Crystal Chemistry of Incommensurate and Modulated Mixed-layer Minerals. Nauka, Moscow, 140 pp. (in Russian).

Palin E.J., Dove M.T., Redfern S.A.T., Bosenick A., Sainz-Diaz C.I. \& Warren M.C. (2001) Computational study of tetrahedral Al-Si ordering in muscovite. Physics and Chemistry of Minerals, 28, $534-544$.

Pavese A. (2002) Neutron powder diffraction and Rietveld analysis; application to crystal-chemical studies of minerals at non-ambient conditions. European Journal of Mineralogy, 14, 241 -249.

Pavese A., Ferraris G., Pishedda V. \& Fauth F. (2001) $\mathrm{M} 1$-site occupancy in $3 \mathrm{~T}$ and $2 \mathrm{M}_{1}$ phengites by low temperature neutron powder diffraction: reality or artefact? European Journal of Mineralogy, 13, $1071-1078$.

Plançon A. (1981) Diffraction layer structures containing different kinds of layers and stacking faults. Journal of Applied Crystallography, 14, 300-304.

Plançon A. (2001) Order-disorder in clay mineral structure. Clay Minerals, 36, 1-14.

Plançon A. (2002) New modeling of X-ray diffraction by disordered lamellar structures, such as phyllosilicates. American Mineralogy, 87, 1672 -1677.

Plançon A. (2003) Modelling X-ray diffraction by lamellar structures composed of electrically charged layers. Journal of Applied Crystallography, 36, $146-153$.

Plançon A. \& Drits V.A. (1994) Expert system for structural characterization of phyllosilicates: I. Description of the expert system. Clay Minerals, 29, 33-38.

Plançon A. \& Drits V.A. (2000) Phase analysis of clays using an expert system and calculation programs for X-ray diffraction by two- and three-component mixed-layer minerals. Clays and Clay Minerals, 48, 57-62.

Plançon A. \& Tchoubar C. (1977) Determination of structural defects in phyllosilicates by X-ray powder diffraction. I. Principle of calculation of the diffraction phenomenon. Clays and Clay Minerals, 25, $430-435$.

Plançon A., Giese R.F., Snyder R., Drits V.A. \& Bookin A.S. (1989) Stacking faults in the kaolin-group minerals: Defect structures of kaolinite. Clays and Clay Minerals, 37, 203-210.

Reynolds R.C. (1980) Interstratified clay minerals. Pp. 249-303 in: Crystal Structures of Clay Minerals and their X-ray Identification (G.W. Brindley \& G. Brown, editors). Monograph 5. Mineralogical Society, London.

Reynolds R.C. (1985) NEWMOD: A computer program for the calculation of one-dimensional diffraction powders of mixed-layer clays. Published by the author, 8 Brook Road, Hanover, NH 03755, USA.

Reynolds R.C. (1988) Mixed-layer chlorite minerals. Pp. 601-629 in: Hydrous Phyllosilicates (exclusive of micas) (S.W. Bailey, editor). Reviews in Mineralogy, 19. Mineralogical Society of America, Washington, D.C.

Reynolds R.C. (1992) X-ray diffraction study of illitesmectite from rocks, $<1 \mu \mathrm{m}$ randomly oriented powders, and $<1 \mu \mathrm{m}$ oriented powder aggregates: the absence of laboratory-induced artifacts. Clays and Clay Minerals, 40, 387-396.

Reynolds R.C., Jr. (1993) Three-dimensional X-ray diffraction from disordered illite: simulation and interpretation of the diffraction patterns. Pp. 44-78 in: Computer Applications to $X$-ray Diffraction Methods (R.C. Reynolds and J. Walker, editors). 
CMS, Workshop Lectures 5. Clay Minerals Society, Bloomington, Indiana.

Reynolds R.C. \& Thompson C.H. (1993) Illites from the Postam sandstone of New York, a probable noncentrosymmetric mica structure. Clays and Clay Minerals, 41, 66-72.

Ryan P.C. \& Reynolds R.C. (1997) The chemical composition of serpentine-chlorite in the Tuscaloosa formation, United States Gulf Coast: EDX vs XRD determinations, implications for mineralogic reactions and the origin of anatase. Clays and Clay Minerals, 45, 339-352.

Sainz-Diaz C.I., Timon V., Botella V. \& HernandezLaguna A. (2000) Isomorphous substitution effect on the vibration frequencies of hydroxyl groups in molecular cluster models of the clay octahedral sheet. American Mineralogist, 85, 1038-1045.

Sainz-Diaz C.I., Caudros J. \& Hernandez-Laguna A. (2001a) Analysis of cation distribution in the octahedral sheet of dioctahedral 2:1 phyllosilicates by using inverse Monte Carlo methods. Physics and Chemistry of Minerals, 28, 445-454.

Sainz-Diaz C.I., Hernandez-Laguna A. \& Dove M.T. (2001b) Modeling of dioctahedral 2:1 phyllosilicates by means of transferable empirical potentials. Physics and Chemistry of Minerals, 28, 130-141.

Sainz-Diaz C.I., Timon V., Botella V., Artacho E. \& Hernandez-Laguna A. (2002) Quantum mechanical calculations of dioctahedral 2:1 phyllosilicates: Effect of octahedral cation distribution in pyrophillite, illite and smectite. American Mineralogist, 87, $958-965$.

Sakharov B.A., Besson G., Drits V.A., Kameneva M.Y., Salyn A.L. \& Smoliar B.B. (1990) X-ray study of the nature of stacking faults in the structure of glauconites. Clay Minerals, 25, 419-435.

Sakharov B.A., Lindgreen H., Salyn A. \& Drits V.A. (1999a) Determination of illite-smectite structures using multispecimen X-ray diffraction profile fitting. Clays and Clay Minerals, 47, 555-566.

Sakharov B.A., Lindgreen H., Salyn A. \& Drits V.A. (1999b) Mixed-layer kaolinite-illite-vermiculite in North Sea shales. Clay Minerals, 34, 333 -344.

Sakharov B.A., Plançon A. \& Drits V.A. (1999c) Influence of outer surface structure of crystals on X-ray diffraction. Program with Abstracts, European Clay Groups Association, September, 1999, Krakow, Poland, p.129.

Schmidt D. \& Livi K.J.T. (1999) HRTEM and SAED investigations of polytypism, stacking disorder, crystal growth, and vacancies in chlorites from subgreenschist facies outcrops. American Mineralogist, 84, 160-170.

Schroeder P.A. (1993) A chemical, XRD, and ${ }^{27}$ Al MAS NMR investigation of Miocene gulf coast shales with application to understanding illite-smectite crystal chemistry. Clays and Clay Minerals, 41, 668-679.
Schroeder P.A. \& Pruett R.J. (1996) Fe ordering in kaolinite: Insights from ${ }^{29} \mathrm{Si}$ and ${ }^{27} \mathrm{Al}$ MAS NMR spectroscopy. American Mineralogist, 81, 26-38.

Slonimskaya M.V., Besson G., Dainyak L.G., Tchoubar C. \& Drits V.A. (1986) The interpretation of the IR spectra of celadonites and glauconites in the region of $\mathrm{OH}-$ stretching frequencies. Clay Minerals, 21, $377-388$

Środoń J. (2002) Quantitative mineralogy of sedimentary rocks with emphasis on clays and with applications to K-Ar dating. A Journal of Mineral Sciences, 66, 677-687.

Środoń J., Andreoli C., Elsass F. \& Robert M. (1990) Direct high-resolution transmission electron microscopic measurement of expandability of mixed-layer illite-smectite in bentonite rock. Clays and Clay Minerals, 38, 373-379.

Środoń J., Eberl D.D. \& Drits V.A. (2000) Evolution of fundamental-particle size during illitization of smectite and implications for reaction mechanism. Clays and Clay Minerals, 48, 446-458.

Strawn D., Doner H., Zavarin M. \& McHugo S. (2002) Microscale investigation into the geochemistry of arsenic, selenium and iron in soil developed in pyritic shale materials. Geoderma, 108, $237-257$.

Tsipursky S.I. \& Drits V.A. (1984) The distribution of octahedral cations in the 2:1 layers of dioctahedral smectites studied by oblique texture electron diffraction. Clay Minerals, 19, 177-193.

Tsipursky S.I., Eberl D.D. \& Buseck P.R. (1992) Unusual tops (bottoms?) of particles of $1 M$ illite from the Silverton cadera. Abstracts of the Annual meeting of ASA, CSSA, SSSA, and CMS, Minneapolis, USA, p. 56.

Uhlik P., Šuchá V., Elsass F. \& Čaplovičova M. (2000) High Resolution Transmission Electron Microscopy of mixed-layer clays dispersed in PVP-10: A new technique to distinguish detrital and authigenic illitic material. Clay Minerals, 35, 781 -789.

Vantelon D., Pelletier M., Michot L.J., Barres O. \& Thomas F. (2001) Fe, Mg and Al distribution in the octahedral sheet of montmorillonites. An infrared study in the $\mathrm{OH}-$ bending region. Clay Minerals, 36, $369-379$.

Vinograd V.L. (1995) Substitution of ${ }^{\mathrm{IV}} \mathrm{Al}$ in layer silicates: Calculation of the Al-Si configurational entropy according to ${ }^{29} \mathrm{Si}$ NMR spectra. Physics and Chemistry of Minerals, 22, 87-89.

Warr L.N. \& Neito F. (1998) Crystal thickness and defect density of phyllosilicates in low-temperature metamorphic pelites: a TEM and XRD study of clay mineral crystallinity index standards. The Canadian Mineralogist, 36, $1453-1474$.

Warshaw C.M (1959) Experimental studies of illites. Clays and Clay Minerals, 7, 303-316.

Ylagan R.F., Altaner S.P. \& Pozzuoli A. (2000) Reaction mechanisms of smectite illitization asso- 
ciated with hydrothermal alteration from Ponza island, Italy. Clays and Clay Minerals, 48, 610-631.

Zvyagin B.B., Rabotnov V.T., Sidorenko O.V. \&

Kotelnikov D.D. (1985) Unique mica consisting of noncentrosymmetric layers. Izvestiya Akademii Nauk S.S.S.R, Seriya Geologicheskaya, 35, 121-124 (in Russian).

Zvyagin, B.B. \& Drits V.A. (1996) Interrelated features of structure and stacking of kaolin mineral layers. Clays and Clay Minerals, 44, 297-303

Zviagina B.B., McCarty D.K., Środoń J. \& Drits V.A. (2002) Interpretation of IR spectra of dioctahedral 2:1 phyllosilicates in the region of $\mathrm{OH}$ stretching vibrations. Proceedings of the $18^{\text {th }}$ General Meeting of the International Mineralogical Association, September 2002, Edinburgh, UK, p. 158. 